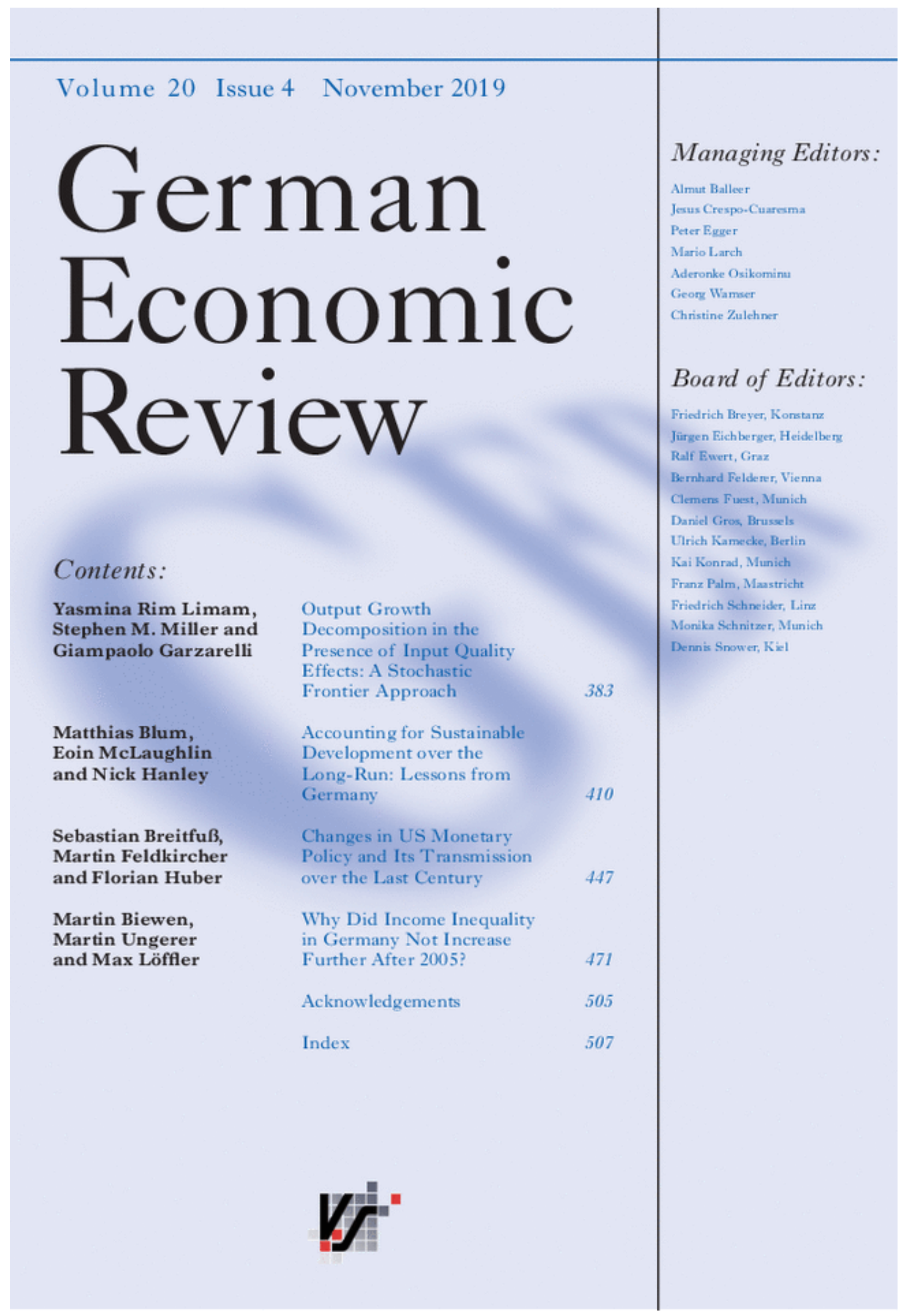




\section{German Economic Review}

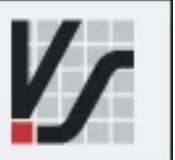

Edited By: Almut Balleer, Jesus Crespo-Cuaresma, Peter Egger, Mario Larch, Jean-Marie Lozachmeur, Aderonke Osikominu, Georg Wamser, Christine Zulehner Impact factor: 0.86

2019 Journal Citation Reports (Clarivate Analytics): 275/371 (Economics)

Online ISSN: 1468-0475

(c) Verein für Socialpolitik

As of 2020, German Economic Review is no longer published by Wiley. Current content can be found on the new publisher's website: https://www.degruyter.com/view/j/ger

\section{Recent issues}




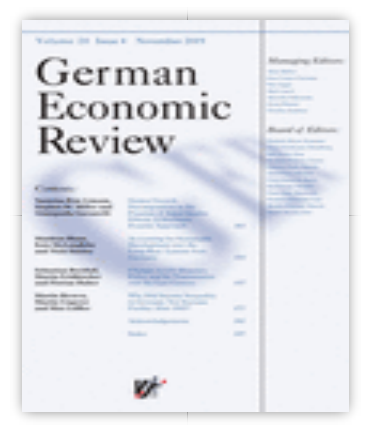

\section{Volume 20, Issue 4}

Pages: i-iv, 383-510, e1-e1053

November 2019

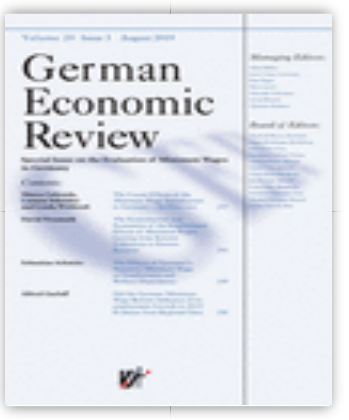

Volume 20, Issue 3

Special Issue on the Evaluation of Minimum Wages in Germany

Pages: i-iv, 257-381

August 2019

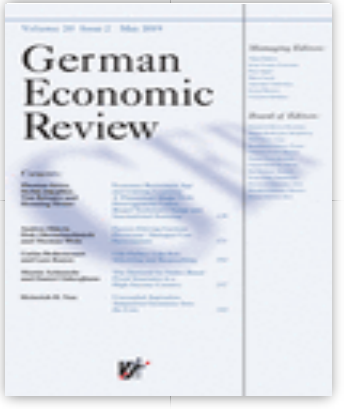

Volume 20, Issue 2

Pages: i-iv, 129-256

May 2019

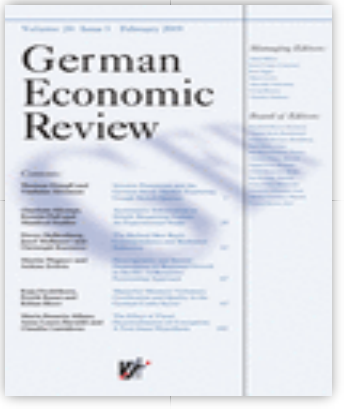

Volume 20, Issue 1

Pages: i-iv, 1-128

February 2019

\section{GER Data Archive}

The GER Data Archive, which is hosted by a server belonging to the ZBW Journal Data Archive, a subdivision of the German National Library of Economics, contains data for all papers submitted and accepted after January 2017, unless these data are confidential. Access the GER Data Archive 
Published on behalf of Verein für Socialpolitik

More from this journal

Wiley Job Network

\author{
About Wiley Online Library \\ Privacy Policy \\ Terms of Use \\ Cookies \\ Accessibility \\ Help \& Support \\ Contact Us \\ Opportunities \\ Subscription Agents \\ Advertisers \& Corporate Partners \\ Connect with Wiley \\ The Wiley Network \\ Wiley Press Room
}




\title{
Output Growth Decomposition in the Pres- ence of Input Quality Effects: A Stochastic Frontier Approach
}

\section{Yasmina Rim Limam}

Université de Carthage \& IPEG

Giampaolo Garzarelli

Sapienza - Università di Roma \&

IPEG, University of the

Witwatersrand

\author{
Stephen M. Miller \\ University of Nevada, Las Vegas \& \\ University of Connecticut (Emeritus)
}

\begin{abstract}
How do physical capital accumulation and total factor productivity (TFP) individually add to economic growth? We approach this question from the perspective of the quality of physical capital and labor, namely the age of physical capital and human capital. We build a unique dataset by explicitly calculating the age of physical capital for each country and each year of our time frame and estimate a stochastic frontier production function incorporating input quality in five regions of countries (Africa, East Asia, Latin America, South Asia and West). Physical capital accumulation generally proves much more important than either the improved quality of factors or TFP growth in explaining output growth. The age of capital decreases growth in all regions except in Africa, while human capital increases growth in all regions except in East Asia.
\end{abstract}

JEL classification: $D 24, E 10, E 22, F 43, O 47$.

Keywords: Age of physical capital; embodiment hypothesis; output growth; stochastic frontier; total factor productivity.

\section{INTRODUCTION}

A large body of theoretical and empirical literature has examined output growth decomposition. The answer from growth accounting sees the separation of growth into two components: one component related to factor accumulation, most often accounted for by physical and human capital, and the other accounted for by total factor productivity (TFP), a lumpy term often associated with technological change - the so-called Solow (1956) residual. Early growth accounting finds that TFP represents the largest share of output growth in developed countries. In contrast, more recent growth accounting rejects the importance of TFP and concludes that it is factor accumulation that accounts for most cross-country income differences (e.g. Baier et al., 2006). Cross-country regression analysis - chiefly in endogenous growth (Lucas, 1988; Romer, 1986) - instead seeks to explain the residual using economic variables, such as trade openness 
and research and development (e.g. Miller and Upadhyay, 2000; Parente and Prescott, 2005). These studies too present mixed results about the main components of growth, even though they favor physical capital accumulation.

Both growth accounting and cross-country regressions assume that TFP is a residual, not allowing the distinction between technological change and technical efficiency (Bosworth and Collins, 2003). Frontier studies add one more term to TFP - technical efficiency, which provides a more precise decomposition of the Solow residual. This measure of TFP is therefore no longer limited to technological change; rather, similarly to the notion of world technology frontier (e.g. Acemoglu et al., 2006), it also incorporates technical efficiency, providing a more precise decomposition of the Solow residual.

In addressing whether factor accumulation or TFP growth explains most of output growth, most early frontier applications confirm the hypothesis that factor accumulation and not TFP growth explains the bulk of output growth (Henderson and Russell, 2005; Kumar and Russell, 2002; Kumbhakar and Wang, 2005; Nissan and Niroomand, 2006). More recent frontier applications instead do not agree on an answer. For example, Makiela (2009) finds that factor accumulation explains the biggest share of growth, while Pires and Garcia (2012) find that TFP growth explains a significant part of growth. Thus, results about the main components of growth remain mixed. ${ }^{1}$

Motivated by these mixed results, this article tackles the question of the determinants of output growth by focusing on input quality. That is, it considers the age of the capital stock for physical capital and the level of education of the population (human capital) for labor.

Most theoretical work in economic growth shares an assumption about production, namely that units of physical capital and labor combine with human capital to produce final units of output. The quantity of physical capital stock changes over time through investment flows and depreciation - thus, treating all units of capital equally. The assumption that units of physical capital are homogenous across time appears unreasonable, for growth can arise from the employment of more capital goods or from the employment of improved ones (e.g. Aghion and Howitt, 2007).

One commonly used approach to account for the quality of physical capital employs efficient units of capital (corrected for the age effect) instead of physical ones (e.g. Hulten, 1992). In this efficient units approach, one constructs capital series where capital depreciates physically (at a rate that can be equal or can be different by country or by sector) as well as becomes technologically obsolete. Most studies that use efficient units of physical capital (Gittleman et al., 2006; Shinada, 2011) seem to agree, however, that the inclusion of the age effect adjusts TFP upward, and causes some smoothing of TFP. Instead of correcting the capital stock using efficient units of capital, we present a simple specification where the productivity of capital directly depends on its average age: physical capital contributes more to output the 'newer' it is, suggesting that physical capital can positively affect growth either through its physical amount or through its average age. The rationale for bringing in the age of physical capital, as

1. Bosworth and Collins (2003) offer an analysis about possible causes of diversity of results. 


\section{Output Growth Decomposition with Input Quality Effects}

empirically elaborated in the next section, rests on the so-called embodiment hypothesis.

In addition to the quality of physical capital, we account for the quality of labor using human capital, which is recognized as an important factor for growth. Yet, its influence on growth remains debated, resulting in two trends in the literature. The first trend considers human capital as a direct input in production (e.g. Islam, 1995; Mankiw et al., 1992); while the second sees it as multiplicatively augmenting labor (e.g. Benhabib and Spiegel, 1994; Turner et al., 2013). We posit that human capital enters production through its influence on labor productivity: labor contributes more to total output the higher is the level of human capital.

We accordingly build a unique dataset of the average age of physical capital for 90 countries grouped into five regions (Africa, East Asia, Latin America, South Asia and West) and over the period 1960-2007. We then introduce a novel production function specification where average age affects the productivity of physical capital and the level of human capital affects the productivity of labor. We subsequently determine for each region, through stochastic frontier, the relative contributions of physical capital accumulation and TFP to total growth in the presence of input quality effects. As mentioned above, the frontier methodology offers the advantage of extracting efficiency from TFP.

Our empirical approach allows the assessment of different effects on growth. First, it sheds light on the relative importance of physical capital accumulation and TFP when the quality of inputs is included. Second, analogously to Gapinski (1999), it allows the separation between the purely input quantity effect from the input quality effect. Third, thanks to the inclusion of input quality, TFP growth decomposes into three effects: input quality change, technical efficiency change, and technological change. To the best of our knowledge, no prior work exists that examines these effects in an analogous manner.

Our principal results can be reported succinctly. The decomposition of output growth demonstrates that even after accounting for input quality, physical capital accumulation generally proves much more important than either the improved quality of factors or TFP growth in explaining output growth. The age of capital decreases growth in all regions except in Africa (the older the capital, the slower the growth), while education increases growth in all regions except in East Asia. Technological change exhibits the highest effect on growth in East Asia and the lowest in South Asia. Finally, our findings indicate that whenever the age of capital is significant and with the right sign, technology is improving.

This article is most closely related to Koop et al. (2000), which constructs a production function where observed units of inputs are transformed into efficient ones using corrective variables; our production specification instead differs by accounting for the quantity and quality of inputs separately. Henderson and Russell (2005), another related work, decomposes output growth in the context of a non-parametric frontier. We employ a parametric one. In its parametric stochastic variant, frontier analysis creates more scope to model quality effects through a specific functional form for production. Moreover, unlike Henderson and Russell, we also account for the quality of physical capital.

The rest of the article is organized as follows. We start with the empirical rationale for considering the age of physical capital (section 2), after which we 
calculate the capital stock and its average age (section 3). Our empirical approach is described next (section 4), followed by our findings (section 5). The conclusion wraps up (section 6).

\section{RATIONALE FOR INCORPORATING THE AGE OF PHYSICAL CAPITAL}

As previously noted, the rationale for the inclusion of the average age of physical capital is the embodiment hypothesis, which suggests that older capital contributes less to TFP than newer capital. The intuition is that older physical capital embodies older technology, which, ceteris paribus, is less productive. ${ }^{2}$

The hypothesis has been tested empirically at different levels (aggregate, industry), and has not always been proven to hold (e.g. Caselli, 2005; Whelan, 2007). A common explanation given to justify this finding is that most databases already adjust for the quality of physical capital through prices. The same literature, however, recognizes that these adjustments may not entirely capture the improved quality of physical capital. Hence, some quality effect still may be unaccounted for. Another explanation relates to the construction of the capital stock series itself. This explanation rests on the belief that the construction of the series places too little weight on old units of investment. Consequently, it does not appropriately substantiate for the productive effects of different units of investment.

We test the embodiment hypothesis by regressing the growth of a measure of TFP against the growth of lagged investment series. ${ }^{3}$ If the hypothesis holds, we expect the growth of more distant investment lags to exert less on current TFP growth than less distant lags. We follow Caselli (2005) and measure TFP as $\frac{Y}{L^{(1-\alpha)}}$, where $Y$ is total output, $L$ is units of labor and $\alpha$ is the elasticity of output with respect to capital. For the purposes of this section, $\alpha$ is aligned with standard practice, namely it is set equal to $1 / 3$. In the rest of the article, however, $\alpha$ is modeled as a function of the age of physical capital, which, of course, is the pivot of the analysis.

We estimate a simple cross-country OLS regression where the dependent variable, namely growth in TFP over the period 1960-2007, is regressed against the growth in investment in 1965, 1975, 1985, 1995 and 2007 in the sample of 90 countries (one observation per country). To have a broader picture, we re-estimate the same cross-country regression with weights given to growth in investment. Both regressions are corrected for heteroskedasticity. See Appendix A for the sample of 90 countries.

We calculate the variables using data from the Penn World Tables 6.3 (PWT6.3) on real GDP per capita, investment as a share of GDP, population, and real GDP per worker. Investment comes from real GDP per capita (variable $r g d p l$ ), population, and the investment as a share of GDP (variable $k i$ ) while labor

2. One of the cetera that is kept paria is the absence of other tradeoffs that may tip the technology adoption balance. In the case of space exploration, for instance, reliable technology is more valuable than latest technology. A recent illustration is NASA's Orion Multi-Purpose Crew Vehicle (Orion MPCV) spacecraft. See http://www.computerworld.com/article/2855604/the-orion-spacec raft-is-no-smarter-than-your-phone.html.

3. We regress growth rates instead of levels of the investment series to avoid possible multicollinearity issues. 


\section{Output Growth Decomposition with Input Quality Effects}

emanates from real GDP per capita (variable rgdpl2) and real GDP per worker (variable rgdpl2worker). ${ }^{4}$

Table 1 OLS regressions, total factor productivity growth as dependent variable

Variable

Coefficient

Panel A: Simple OLS

\begin{tabular}{lc}
\hline Constant & $0.007^{*}$ \\
GInv07 & $(1.72)$ \\
& 0.211 \\
GInv95 & $(1.16)$ \\
& $0.242^{* *}$ \\
GInv85 & $(2.23)$ \\
GInv75 & -0.045 \\
GInv65 & $(-0.49)$ \\
$R^{2}$ & 0.013 \\
& $(0.27)$ \\
\end{tabular}

Test of equality of coefficients

$F(4,84)$

Panel B: OLS with weights

\begin{tabular}{lc}
\hline Constant & $0.007^{*}$ \\
GInv07 & $(1.72)$ \\
& 0.210 \\
$(1-\delta)^{12} G \operatorname{Inv} 95$ & $(1.16)$ \\
$(1-\delta)^{22} G \operatorname{Inv} 85$ & $3.30^{\star *}$ \\
$(1-\delta)^{32} G \operatorname{In} v 75$ & $(2.23)$ \\
$(1-\delta)^{42} G \operatorname{In} v 65$ & -0.30 \\
$R^{2}$ & $(-0.49)$ \\
\end{tabular}

Test of equality of coefficients

$F(4,84)$

Notes: $N=90$. GInv is growth in investment, and the number attached to it is the year. $\delta$ is the depreciation rate that is set equal to $7 \%$. The numbers in parentheses for the regression coefficients are $t$-statistics; ${ }^{*}$ Significant at the $5 \%$; *Significant at the $10 \%$; the numbers in parentheses for the $F$-tests are $p$-values.

4. Heston et al. (2009); http://www.rug.nl/research/ggdc/data/pwt/pwt-6.3. 


\section{Y. R. Limam et al.}

Table 1 displays the results, which are in line with the embodiment hypothesis. Panel A presents the regression of TFP growth against the growth of investment in 1965, 1975, 1985, 1995 and 2007. We see that different lags of investment growth carry different coefficients (even if not all significant) that are also generally larger for more recent lags, suggesting that more recent investment growth contributes more to TFP growth than older investment growth. Panel B of Table 1 displays the results of the OLS with weights, which are in line with those of the simple OLS: the coefficients on distant lags are generally smaller than those on more recent lags. To check the statistical difference of the coefficients, we perform a linear restrictions test on both estimations. Results show that the hypothesis that coefficients are pairwise equal is rejected at the $1 \%$ significance level for both the simple and the weighted OLS.

The bottom line of our regression exercise is that we cannot a priori reject the embodiment hypothesis, entailing that there may be a negative correlation between TFP and the age of physical capital. There is accordingly scope to more precisely ascertain the relation between TFP and the age of physical capital by considering the effect of the age of capital on productivity of capital.

\section{CALCULATION OF THE CAPITAL STOCK AND ITS AVERAGE AGE}

This section estimates (non-quality adjusted) physical capital stocks and the average age of physical capital for the 90 countries over the period 1960-2007. The countries are grouped into five regions as follows: Africa (30 countries), Latin America (21 countries), East Asia (8 countries), South Asia (8 countries) and the West (23 countries). Our country regions are the same as those of Henderson and Russell (2005) and Koop et al. (2000), with the only exception that the former further distinguishes between OECD and non-OECD countries. Refer to Appendix A for the five regions.

\subsection{Calculating the capital stock}

In order to estimate the capital stock series, we first estimate the initial capital stock (1960) for each country. Then, based on that starting value, and available investment series, we use the perpetual inventory method to derive the capital stocks for the entire period.

The initial capital stock is calculated using the steady-state method (King and Levine, 1994). The method assumes that the capital-output ratio is constant in the steady state. That is, for each country and for time period $t$, physical capital and real output grow at the same rate $\phi_{t}^{*}=d K_{t} / K_{t}=d Y_{t} / Y_{t}$, where $\phi_{t}^{*}$ equals the steady-state growth rate, $K_{t}$ equals the capital stock, and $Y_{t}$ equals real GDP. Since $d K_{t}=I_{t}-\delta K_{t}$, then $\left(d K_{t} / K_{t}\right)=\left(I_{t} / K_{t}\right)-\delta$, where $I_{t}$ equals gross investment, and $\delta$ is the (physical) depreciation rate of physical capital. ${ }^{5}$

5. The notation means that $d K_{t}=K_{t+1}-K_{t}$ and $d Y_{t}=Y_{t+1}-Y_{t}$. 


\section{Output Growth Decomposition with Input Quality Effects}

We assume that $\delta$ is constant across countries and time at $7 \%$ per year (King and Levine, 1994). ${ }^{6}$ Consequently, the steady-state capital-output ratio for country $j$ is derived as follows:

$$
\kappa_{j}^{*}=i_{j}^{*} /\left(\delta+\phi_{j}^{*}\right),
$$

where $\kappa_{j}^{*}$ equals the steady-state capital-output ratio, and $i_{j}^{*}$ equals the steady-state investment rate for country $j$. We assume that the steady-state investment rate equals the average investment rate for the entire period. We also assume that the steady-state growth rate equals a weighted average of the country's growth rate and the world growth rate. Specifically, the steady-state growth rate of country $j$ is

$$
\phi_{j}^{*}=\lambda \phi_{j}+(1-\lambda) \phi_{w},
$$

where $\lambda=0.25$ is a measure of mean reversion in the growth rates (Easterly et al., 1993), and $\phi_{w}=0.04$ equals the world growth rate over the 48-year period.

The calculation of the steady-state capital-output ratio assumes that the capital-output ratio remains fixed. We use the steady-state capital-output ratio to calculate each country's initial capital stock. As the steady-state capital-output ratio applies to the initial year, the following holds:

$$
K_{j, 0}=\kappa_{j} Y_{j, 0},
$$

where $Y_{j, 0}$, and $K_{j, 0}$ equal country $j^{\prime}$ s initial GDP and initial capital stock (1960). The calculation of the capital stock for the remaining years uses the perpetual inventory method first developed by Harberger (1978):

$$
K_{j, t+1}=I_{j, t}+(1-\delta) K_{j, t},
$$

where $K_{j, t}$ equals the capital stock and $I_{j, t}$ equals gross investment for country $j$ at time $t$. After substitutions, equation (4) generates a function of the initial capital stock and investment flows:

$$
K_{j, t}=\sum_{i=1}^{t}(1-\delta)^{i-1} I_{j, t-i}+(1-\delta)^{t} K_{j, 0} .
$$

Equation (5) produces a time-series physical capital stock for all countries.

Table 2 reports the average output, physical capital and labor for each decade and each region, as well as the minimum and maximum averages for countries over the entire sample. Notice how, except for East Asia during the last decade, all variables increase continuously over the period and in all regions. The West possesses the highest averages of real output and physical capital in all five decades, while Africa owns the lowest averages. The labor force, however, emerges as the highest in East Asia and the lowest in Africa.

6. Kamps (2006) disaggregates physical capital into three categories (private non-residential, government and private residential) and argues that the time profile of depreciation depends on the category of capital. Berlemann and Wesselhöft (2014) use a similar disaggregation approach in calculating their physical capital series. Here, the distinction between units of physical capital is based solely on the difference in the age of capital regardless of the sector or industry in which the capital is used. Capital depreciates physically at a constant rate $(\delta)$ while technology becomes more obsolete the older the capital. 


\section{Y. R. Limam et al.}

Table 2 Average value of $Y, K$ and $L$ by decade and by region (90 countries)

\begin{tabular}{|c|c|c|c|c|c|c|c|c|}
\hline Region & $60 \mathrm{~s}$ & $70 \mathrm{~s}$ & $80 \mathrm{~s}$ & $90 \mathrm{~s}$ & $00-07$ & $\begin{array}{l}\text { Average } \\
60-07\end{array}$ & Minimum & Maximum \\
\hline \multicolumn{9}{|c|}{ Panel A: $Y$ (in 2005 US\$ billions) } \\
\hline Africa & 13.85 & 21.42 & 31.51 & 42.23 & 57.34 & 33.27 & $\begin{array}{c}1.15 \\
\text { (Gambia, The) }\end{array}$ & $\begin{array}{c}261.06 \\
\text { (South Africa) }\end{array}$ \\
\hline East Asia & 172.56 & 356.32 & 612.72 & $1,101.02$ & 560.66 & 560.66 & $\begin{array}{c}62.92 \\
\text { (Singapore) }\end{array}$ & $\begin{array}{c}2,468.42 \\
\text { (China) }\end{array}$ \\
\hline Latin America & 54.50 & 99.79 & 137.79 & 174.07 & 223.51 & 137.93 & $\begin{array}{c}8.75 \\
\text { (Nicaragua) }\end{array}$ & $\begin{array}{l}983.70 \\
\text { (Brazil) }\end{array}$ \\
\hline South Asia & 112.93 & 178.35 & 285.06 & 460.10 & 713.63 & 350.01 & $\begin{array}{c}6.74 \\
\text { (Papua New Guinea) }\end{array}$ & $\begin{array}{l}1,512.14 \\
\text { (India) }\end{array}$ \\
\hline West & 133.51 & 211.35 & 270.76 & 346.36 & $2,176.75$ & 627.74 & $\begin{array}{c}5.66 \\
\text { (Iceland) }\end{array}$ & $\begin{array}{l}\text { 6,874.71 } \\
\text { (U.S.) }\end{array}$ \\
\hline \multicolumn{9}{|c|}{ Panel B: K (in 2005 US\$ billions) } \\
\hline Africa & 17.28 & 28.28 & 51.15 & 61.76 & 74.53 & 46.60 & $\begin{array}{c}0.85 \\
\text { (Uganda) }\end{array}$ & $\begin{array}{c}428.77 \\
\text { (Algeria) }\end{array}$ \\
\hline East Asia & 405.02 & 853.27 & $1,576.30$ & $2,940.43$ & $1,443.75$ & $1,443.75$ & $\begin{array}{c}205.50 \\
\text { (Singapore) }\end{array}$ & $\begin{array}{c}8,388.42 \\
\text { (Japan) }\end{array}$ \\
\hline Latin America & 95.78 & 167.09 & 271.31 & 332.06 & 429.17 & 259.08 & $\begin{array}{l}12.57 \\
\text { (Haiti) }\end{array}$ & $\begin{array}{l}2,639.85 \\
\text { (Brazil) }\end{array}$ \\
\hline South Asia & 144.72 & 215.51 & 374.48 & 636.36 & 987.64 & 471.74 & $\begin{array}{c}11.57 \\
\text { (Papua New Guinea) }\end{array}$ & $\begin{array}{l}1,939.82 \\
\text { (India) }\end{array}$ \\
\hline West & 338.42 & 558.80 & 763.35 & 992.07 & $5,030.12$ & $1,536.55$ & $\begin{array}{c}18.58 \\
\text { (Iceland) }\end{array}$ & $\begin{array}{l}15,316.46 \\
\text { (U.S.) }\end{array}$ \\
\hline \multicolumn{9}{|c|}{ Panel C: $L$ (in millions) } \\
\hline Africa & 2.38 & 3.00 & 4.00 & 5.40 & 6.67 & 4.22 & $\begin{array}{c}0.37 \\
\text { (Gabon) }\end{array}$ & $\begin{array}{c}14.30 \\
\text { (Egypt) }\end{array}$ \\
\hline East Asia & 53.27 & 68.22 & 86.72 & 105.02 & 105.81 & 84.35 & $\begin{array}{c}1.34 \\
\text { (Singapore) }\end{array}$ & $\begin{array}{l}557.50 \\
\text { (China) }\end{array}$ \\
\hline Latin America & 3.57 & 4.84 & 6.34 & 8.85 & 11.37 & 6.81 & $\begin{array}{c}0.45 \\
\text { (Trinidad \& Tobago) }\end{array}$ & $\begin{array}{c}54.17 \\
\text { (Brazil) }\end{array}$ \\
\hline South Asia & 36.62 & 44.98 & 56.82 & 71.39 & 85.75 & 58.30 & $\begin{array}{c}1.44 \\
\text { (Papua New Guinea) }\end{array}$ & $\begin{array}{l}288.25 \\
\text { (India) }\end{array}$ \\
\hline West & 8.84 & 10.07 & 11.69 & 13.00 & 14.23 & 11.46 & $\begin{array}{c}0.12 \\
\text { (Iceland) }\end{array}$ & $\begin{array}{l}112.57 \\
\text { (U.S.) }\end{array}$ \\
\hline
\end{tabular}

Note: The minimum and maximum values are based on individual country averages.

Table 3 reports the average capital-output and capital-labor ratios per decade and per region as well as the minimum and maximum averages for countries over the entire sample. Notice how the capital-output ratio exhibits ups and downs for all regions without a clear trend while the capital-labor ratio is mostly rising. The West ranks first in terms of both ratios while Africa and South Asia have the lowest capital-output and capital-labor ratios, respectively. 
Output Growth Decomposition with Input Quality Effects

Table 3 Average $K / Y$ and $K / L$ by decade and by region (90 countries)

\begin{tabular}{|c|c|c|c|c|c|c|c|c|}
\hline Region & $60 \mathrm{~s}$ & $70 \mathrm{~s}$ & $80 \mathrm{~s}$ & $90 \mathrm{~s}$ & $00-07$ & $\begin{array}{c}\text { Average } \\
60-07\end{array}$ & Minimum & Maximum \\
\hline
\end{tabular}

Panel A: Capital-output ratio $(K / Y)$

\begin{tabular}{|c|c|c|c|c|c|c|c|c|}
\hline Africa & 1.09 & 1.11 & 1.29 & 1.22 & 1.15 & 1.17 & $\begin{array}{c}0.06 \\
\text { (Uganda) }\end{array}$ & $\begin{array}{c}3.96 \\
\text { (Algeria) }\end{array}$ \\
\hline East Asia & 2.30 & 2.03 & 2.30 & 2.52 & 2.29 & 2.29 & $\begin{array}{c}1.48 \\
\text { (Taiwan) }\end{array}$ & $\begin{array}{c}3.40 \\
\text { (Singapore) }\end{array}$ \\
\hline Latin America & 1.83 & 1.81 & 2.18 & 2.13 & 2.12 & 2.02 & $\begin{array}{c}1.18 \\
\text { (Haiti) }\end{array}$ & $\begin{array}{c}3.28 \\
\text { (Jamaica) }\end{array}$ \\
\hline South Asia & 1.27 & 1.21 & 1.39 & 1.42 & 1.48 & 1.35 & $\begin{array}{c}0.81 \\
\text { (Bangladesh) }\end{array}$ & $\begin{array}{c}1.64 \\
\text { (Papua New Guinea) }\end{array}$ \\
\hline West & 2.69 & 2.82 & 2.96 & 2.91 & 2.53 & 2.78 & $\begin{array}{c}2.10 \\
\text { (United Kingdom) }\end{array}$ & $\begin{array}{c}3.51 \\
\text { (Cyprus) }\end{array}$ \\
\hline
\end{tabular}

Panel B: Capital-labor ratio $(K / L)$

\begin{tabular}{|c|c|c|c|c|c|c|c|c|}
\hline Africa & 7.25 & 9.75 & 12.75 & 11.76 & 11.70 & 10.64 & $\begin{array}{c}0.12 \\
\text { (Uganda) }\end{array}$ & $\begin{array}{c}67.34 \\
\text { (Algeria) }\end{array}$ \\
\hline East Asia & 21.58 & 34.87 & 58.59 & 94.66 & 127.70 & 65.22 & $\begin{array}{c}6.50 \\
\text { (China) }\end{array}$ & $\begin{array}{l}135.20 \\
\text { (Japan) }\end{array}$ \\
\hline Latin America & 26.99 & 33.55 & 40.00 & 36.27 & 38.50 & 34.91 & $\begin{array}{c}5.28 \\
\text { (Haiti) }\end{array}$ & $\begin{array}{c}88.72 \\
\text { (Trinidad \& Tobago) }\end{array}$ \\
\hline South Asia & 4.65 & 5.86 & 8.32 & 10.07 & 11.14 & 7.93 & $\begin{array}{c}3.00 \\
\text { (Bangladesh) }\end{array}$ & $\begin{array}{c}13.37 \\
\text { (Philippines) }\end{array}$ \\
\hline West & 75.95 & 108.87 & 129.81 & 149.56 & 178.67 & 126.48 & $\begin{array}{c}73.23 \\
\text { (Portugal) }\end{array}$ & $\begin{array}{c}198.98 \\
\text { (Luxembourg) }\end{array}$ \\
\hline
\end{tabular}

Note: The minimum and maximum values are based on individual country averages.

\subsection{Calculating the average age of physical capital}

Gapinski (1999) develops a vintage capital model assuming a constant returns to scale Cobb-Douglas production function. We adopt a slight modification of Gapinski, where we exclude consideration of the rate of embodiment, to estimate the average age of capital using a discrete-time model:

$$
V_{t}=W A A_{t}=\left[\sum_{i=1}^{t}(t-i)(1-\delta)^{t-i} I_{i-1}+(\bar{V}+t)(1-\delta)^{t} K_{0}\right] / K_{t},
$$

where $V_{t}$ equals the average age of the capital stock at time $t, \bar{V}$ equals the average age of the steady-state capital stock and $W A A$ equals the weighted aggregate age of the capital stock, where investment provides the weights. ${ }^{7}$ Consequently, the average age of capital depends only upon the level of investment, the depreciation rate, and the average age of the steady-state capital stock. We calculate the average age of capital for the countries for which we estimate the capital stock and provide information for each of the five regions that constitute the final analysis.

7. The initial average age assumes a steady-state situation in 1960 . 
Further discussion of equation (6) proves important. First, note that the steadystate capital stock in period zero (i.e. $K_{0}$ by assumption) exhibits an average age of $\bar{V}$. As we move one year ahead in time, the initial capital stock depreciates and ages by one year, which continues for each additional year. Thus, we write $(\bar{V}+t)(1-\delta)^{t} K_{0}$ to capture the weighted age of the initial capital stock after $t$ years, which appears as the last term in the brackets in equation (6). For each additional period beyond period zero, we add investment (i.e. $I_{i}$ ) to the capital stock. Investment in period $i$ only appears in the capital stock in period $(i+1)$ with age equal to zero. Then, moving to time period $t>i$, we write the weighted age of the capital stock from the $i$-th period as $\sum_{i=1}^{t}(t-i)(1-\delta)^{t-i} I_{i-1}$, which appears as the first term in the brackets in equation (6). For example, when $i=t-1$, then the weighted age equals $(1-\delta) I_{t-2}$.

Second, the average age of the steady-state capital stock is calculated as follows. Compare the age of the capital stock at time zero and one. At time zero, we assume that the capital stock equals the steady-state value. Thus, the average age equals $\bar{V}$. In period one, the stock of capital in period zero becomes one year older (i.e. $(\bar{V}+1))$ and it depreciates by $\delta$. The investment in period zero (i.e. $I_{0}$ ) carries on as capital in period one with age equal to zero. Thus, the average age of the capital stock in period one equals the following expression:

$$
V_{1}=\left[(\bar{V}+1)(1-\delta) K_{0}\right] / K_{1},
$$

where

$$
K_{1}=(1-\delta) K_{0}+I_{0}
$$

Assuming that the investment in period one exactly kept the capital stock at its steady-state level in period one, then $V_{1}=\bar{V}$. Substituting equation (8) into (7) and setting $V_{1}=\bar{V}$ produces the following solution for $\bar{V}$ :

$$
\bar{V}=(1-\delta)\left(K_{0} / I_{0}\right)
$$

Since $\left(K_{0} / I_{0}\right)$ equals the steady-state capital-investment ratio, we substitute from equation (1) to obtain the following outcome:

$$
\bar{V}=(1-\delta) /\left(\delta+\phi_{j}^{*}\right)
$$

where $\phi^{*}$ is calculated as in equation (2) and takes a different value for each country. This leads to a different average age of the initial capital stock for each country. Table 4 reports the average age of physical capital for each decade and for the 48year period for each region. Over the period, Africa exhibits the highest age of capital (8.99 years) and East Asia the lowest (6.64 years). The average age of capital is 8.77, 8.26 and 8.66 years in Latin America, South Asia and the West, respectively. On a decade-by-decade basis, the average age of capital equals the highest in the first decade in East Asia and South Asia while it is the highest in the fourth decade in Latin America and the West. In Africa, the average age of capital is at its highest in the last decade. East Asia experiences the fastest decline in the average age of its capital stock in the first three decades before the average age starts increasing again in the 1990s and 2000s. We expect this outcome, since East Asian countries largely focused on industrialization and modernization of their economies during the first three decades of our study (1960-90). The policy shift of Hong Kong and Singapore from import substitution to export promotion strategies and their high investment rates during the 1960s helps to explain their lowest average age of capital. 


\section{Output Growth Decomposition with Input Quality Effects}

Table 4 Average age of physical capital ( $V$ ) in years, by decade and by region (90 countries)

\begin{tabular}{|c|c|c|c|c|c|c|c|c|}
\hline $\begin{array}{l}\text { Decade } \\
\text { Region }\end{array}$ & $60 \mathrm{~s}$ & $70 \mathrm{~s}$ & $80 \mathrm{~s}$ & $90 \mathrm{~s}$ & $00-07$ & Average $60-07$ & Minimum & Maximum \\
\hline Africa & 8.94 & 8.32 & 8.38 & 9.46 & 9.85 & 8.99 & $\begin{array}{c}7.70 \\
\text { (Tunisia) }\end{array}$ & $\begin{array}{c}11.06 \\
\text { (Congo, DR) }\end{array}$ \\
\hline East Asia & 7.67 & 6.64 & 6.11 & 6.13 & 6.64 & 6.64 & $\begin{array}{c}5.84 \\
\text { (Japan) }\end{array}$ & $\begin{array}{c}7.14 \\
\text { (China) }\end{array}$ \\
\hline Latin America & 8.61 & 8.13 & 8.30 & 9.46 & 9.36 & 8.77 & $\begin{array}{c}7.72 \\
\text { (Dominican Republic) }\end{array}$ & $\begin{array}{l}9.96 \\
\text { (Haiti) }\end{array}$ \\
\hline South Asia & 9.03 & 8.71 & 7.60 & 7.90 & 8.05 & 8.26 & $\begin{array}{c}7.70 \\
\text { (Pakistan) }\end{array}$ & $\begin{array}{c}9.34 \\
\text { (Bangladesh) }\end{array}$ \\
\hline West & 8.29 & 7.90 & 8.79 & 9.30 & 9.00 & 8.66 & $\begin{array}{c}7.66 \\
\text { (Israel) }\end{array}$ & $\begin{array}{c}9.80 \\
\text { (France) }\end{array}$ \\
\hline
\end{tabular}

Note: The minimum and maximum values are based on individual country averages.

\section{EMPIRICAL APPROACH}

Stochastic frontier assumes that given inputs, a maximum attainable output exists. The country's production lies on the frontier, if it uses the inputs efficiently, or within the frontier, if it uses the inputs inefficiently (Aigner et al., 1977; Meusen and van den Broeck, 1977). The distance between the frontier and the actual production point measures technical inefficiency. In this context, the Solow residual reflects not only technological change, but also country specific variables that influence a country's success in producing close to its best-practice output.

Over time, a country's performance relative to the frontier includes two factors. First, a country can become more efficient, and get closer to the frontier. Second, the frontier itself can shift over time. Frontier shifts reflect purely technological factors. In addition, a country can move along the frontier by changing inputs. Hence, output growth can be thought of in terms of three components: efficiency change, technological change and input change.

We assume a standard Cobb-Douglas production function, where aggregate output is produced using the aggregate physical capital stock and labor:

$$
Y_{i t}=A_{t} K_{i t}^{\beta_{1 i t}} L_{i t}^{\beta_{2 i t}},
$$

where $Y_{i t}, K_{i t}$ and $L_{i t}$ represent country $i$ 's real GDP, physical capital stock and labor at time $t$. $A_{t}$ equals $A e^{\xi t}$, where $\xi$ measures the rate of technological change. That is to say that, throughout, the $t$ in $\xi$ t represents a simple time trend accounting for technological change from technology affecting production that is not captured by the age of capital. The parameters $\beta_{1 i t}$ and $\beta_{2 i t}$ measure the elasticities of output with respect to capital and labor.

To allow differences in the quality of inputs between countries, we assume that the productivities of capital and labor directly depend on the average age of capital and the level of human capital, respectively. Consequently, we assume that the coefficients $\beta_{1 i t}$ and $\beta_{2 i t}$ are linear functions of capital age and human 


\section{Y. R. Limam et al.}

capital, respectively. Thus,

$$
\beta_{1 i t}=\alpha_{1}+\alpha_{2} V_{i t}
$$

and

$$
\beta_{2 i t}=\omega_{1}+\omega_{2} H_{i t}
$$

where $V_{i t}$ represents country $i$ 's average age of physical capital at time $t$ and $H_{i t}$ represents country i's mean years of secondary education (or human capital) at time $t$. Because older capital incorporates older technology, one expects that the lower the average age, the more productive the capital stock. Similarly, the more educated workers are, the higher the productivity of labor. Consequently, we expect that the sign of $\alpha_{2}$ is negative, and that the sign of $\omega_{2}$ is positive.

After substituting equations (12) and (13) into equation (11) and after taking natural logarithms, equation (11) becomes:

$$
\ln Y_{i t}=\ln A+\alpha_{1} \ln K_{i t}+\alpha_{2} V_{i t} \ln K_{i t}+\omega_{1} \ln L_{i t}+\omega_{2} H_{i t} \ln L_{i t}+\xi t+v_{i t}-u_{i t},
$$

where $v_{i t}$ are independently and identically distributed random errors, iid $\sim N(0$, $\sigma_{v}^{2}$ ), and $u_{i t}$ are distributed independently of $v_{i t}$ and follow a normal distribution, that is $u_{i t} \sim N\left(\mu, \sigma_{u}^{2}\right)$.

We model the one-sided error term as:

$$
u_{i t}=\eta_{i t} u_{i}=\exp [-\eta(t-T)] u_{i} \quad(t=1, \ldots, T ; i=1,2, \ldots, N),
$$

where $\eta$ captures the rate of decline in technical inefficiency (Battese and Coelli, 1992). Thus, the technical efficiency measures for every country and every year are calculated as:

$$
\widehat{T E}_{i t}=\exp \left(-u_{i t}\right)
$$

Battese and Corra (1977) suggest that to facilitate hypothesis testing $\sigma_{u}^{2}$ and $\sigma_{v}^{2}$ be replaced by $\sigma^{2}=\sigma_{u}^{2}+\sigma_{v}^{2}$ and $\gamma=\sigma_{u}^{2} /\left(\sigma_{v}^{2}+\sigma_{u}^{2}\right)$. Under this parameterization, $\gamma$ measures, between zero and one, the share of technical efficiency in explaining the error variation.

We estimate equations (14) and (15) for each region and for the period 19602007. ${ }^{8}$ Data on $Y, K, L$ and $V$ are from our previous calculations. To approximate the level of human capital, we use the mean years of secondary education. These data are from the Barro-Lee Educational Attainment Dataset. ${ }^{9}$ Table 5 provides information on the mean years of education by decade and by region. It shows that the level of education increases across the decades for all regions, the only exception is the sharp decrease experienced by East Asia in the years 2000-07. East Asia experiences the highest mean years of education over the 48-year period followed by Latin America, West, South Asia and Africa.

8. We use FRONTIER Version 4.1: http://www.uq.edu.au/economics/cepa/frontier.php.

9. The data in the Barro-Lee Educational Attainment Dataset (Barro and Lee, 2013) are presented at five-year intervals (http://www.barrolee.com/). Since our time series from 1960 to 2007 requires yearly data, we use the value of the reported year for the subsequent years in each interval (Wang and Wong, 2012). For example, the number for 2000 will be repeated for all the years from 2000 to 2004 . 


\section{Output Growth Decomposition with Input Quality Effects}

Table 5 Mean years of education $(H)$ by decade and by region (90 countries)

\begin{tabular}{|c|c|c|c|c|c|c|c|c|}
\hline $\begin{array}{l}\text { Decade } \\
\text { Region }\end{array}$ & $60 s$ & $70 \mathrm{~s}$ & $80 \mathrm{~s}$ & $90 s$ & $00-07$ & $\begin{array}{c}\text { Average } \\
60-07\end{array}$ & Minimum & Maximum \\
\hline Africa & 0.22 & 0.39 & 0.67 & 1.06 & 1.31 & 0.73 & $\begin{array}{c}0.07 \\
\text { (Mozambique) }\end{array}$ & $\begin{array}{c}2.05 \\
\text { (Ghana) }\end{array}$ \\
\hline East Asia & 1.10 & 1.54 & 2.22 & 2.79 & 1.91 & 1.91 & $\begin{array}{c}0.70 \\
\text { (Thailand) }\end{array}$ & $\begin{array}{c}3.22 \\
\text { (Japan) }\end{array}$ \\
\hline Latin America & 0.57 & 0.89 & 1.38 & 1.78 & 2.19 & 1.36 & $\begin{array}{c}0.52 \\
\text { (Guatemala) }\end{array}$ & $\begin{array}{c}2.24 \\
\text { (Chile) }\end{array}$ \\
\hline South Asia & 0.35 & 0.59 & 0.89 & 1.26 & 1.60 & 0.94 & $\begin{array}{c}0.50 \\
\text { (Nepal) }\end{array}$ & $\begin{array}{c}1.47 \\
\text { (Sri Lanka) }\end{array}$ \\
\hline West & 0.35 & 0.59 & 0.89 & 1.26 & 1.60 & 0.94 & $\begin{array}{c}1.23 \\
\text { (Portugal) }\end{array}$ & $\begin{array}{c}4.70 \\
\text { (U.S.) }\end{array}$ \\
\hline
\end{tabular}

Note: The minimum and maximum values are based on individual country averages.

We perform several hypotheses tests concerning the existence of regional frontiers versus a single world frontier, and the existence and the distribution of the efficiency term, employing log-likelihood tests. We find that the regional frontiers exhibit significantly different technologies and aggregation into a world technology does not seem justified. We further find that the stochastic frontier significantly dominates the OLS model in all regions and the half-normal distribution dominates the truncated normal in all regions except for East Asia. Finally, we test whether technical efficiency is time varying or time invarying. We find that the time-varying technical efficiency dominates in every region, except for Africa. See Table B1 in Appendix B.

We now consider the time-series properties of the data. Panel data require stationarity of the series. If the model is estimated and the series are non-stationary, then the issue of false correlation among the series may arise and the estimated production function would be spurious. In stochastic frontier analysis, this implies that the inefficiency term is meaningless and inaccurate. In the absence of level stationarity, one should consider first differences. If the latter are all stationary, then there could be a long run relationship in the series (i.e. there is cointegration), in which case we can proceed with data analysis. We employ the panel unit-root test of $\mathrm{Im}$ et al. (2003) to check for stationarity in $\ln Y, \ln K, \ln L, V \ln K$ and $H \ln L$. Results indicate that most of the series are non-stationary in level (Table B2, Panel A) but stationary in first difference (Table B2, Panel B). The Johansen Fisher test for panel cointegration rejects the null hypotheses of no cointegration between the series at the $1 \%$ level for all regions (Table B3). This result implies that even though the level series are not stationary, they follow a common trend in the long run, meaning that a long run relationship exists between them and level analysis can be performed. This sets the ground for our stochastic frontier analysis. 


\section{Y. R. Limam et al.}

\section{FINDINGS}

Table 6 displays the results of the regional stochastic frontier estimations from equation (14), where the frontier specification for each region is based on the hypothesis tests as reported in Table B1 in Appendix B. Results show that the coefficients on capital and labor prove significantly positive in all regions. The coefficients on the average age of capital interaction term prove significantly negative in East Asia, Latin America and the West suggesting that the older capital stock exhibits lower productivity in these three regions. The coefficient is positive but insignificant in Africa, which suggests that the age of the capital stock does not affect productivity in Africa. Finally, the coefficient is positive and significant in South Asia, which is an exception to our expectations. The coefficients, however, do not produce sizeable effects, as we shall see later.

The coefficients on the human capital interaction term prove significantly positive in Africa, South Asia and West, and positive and insignificant in Latin America. In East Asia, the coefficient is significant and negative. This result indicates that, with the exception of two regions, higher educational attainment generated more productive labor. The coefficients on the time trend prove significant and positive

Table 6 Frontier results

\begin{tabular}{|c|c|c|c|c|c|}
\hline Variables & Africa & East Asia & Latin America & South Asia & West \\
\hline \multicolumn{6}{|c|}{ Panel A: Production function } \\
\hline Intercept & $\begin{array}{c}4.3376^{\star \star \star *} \\
(14.48)\end{array}$ & $\begin{array}{c}5.6300^{\star * *} \\
(15.73)\end{array}$ & $\begin{array}{c}3.9015^{\star * *} \\
(15.36)\end{array}$ & $\begin{array}{c}3.2950^{* * *} \\
(18.42)\end{array}$ & $\begin{array}{c}4.865^{\star * \star} \\
(10.45)\end{array}$ \\
\hline $\ln K$ & $\begin{array}{c}0.6124^{* * *} \\
(53.35)\end{array}$ & $\begin{array}{c}0.4262^{\star * *} \\
(12.69)\end{array}$ & $\begin{array}{c}0.5569^{* * *} \\
(32.49)\end{array}$ & $\begin{array}{c}0.5698^{* * *} \\
(31.24)\end{array}$ & $\begin{array}{c}0.6589^{* * *} \\
(31.57)\end{array}$ \\
\hline $\ln L$ & $\begin{array}{c}0.3120^{* \star *} \\
(28.77)\end{array}$ & $\begin{array}{c}0.5582^{* * *} \\
(14.61)\end{array}$ & $\begin{array}{c}0.4932^{\star * *} \\
(23.34)\end{array}$ & $\begin{array}{c}0.4415^{\star * *} \\
(25.69)\end{array}$ & $\begin{array}{c}0.2163^{* * *} \\
(7.51)\end{array}$ \\
\hline$V \ln K$ & $\begin{array}{c}0.0005 \\
(1.44)\end{array}$ & $\begin{array}{c}-0.0026^{* * *} \\
(-12.26)\end{array}$ & $\begin{array}{c}-0.0016^{\star * \star} \\
(-5.81)\end{array}$ & $\begin{array}{c}0.0016^{* * *} \\
(5.64)\end{array}$ & $\begin{array}{c}-0.0019^{* * *} \\
(-8.13)\end{array}$ \\
\hline$H \ln L$ & $\begin{array}{l}0.0142^{* \star *} \\
(6.97)\end{array}$ & $\begin{array}{c}-0.0042^{* *} \\
(-2.41)\end{array}$ & $\begin{array}{c}0.0026 \\
(1.10)\end{array}$ & $\begin{array}{c}0.018^{\star * *} \\
(8.48)\end{array}$ & $\begin{array}{l}0.0031^{* * *} \\
\quad(4.48)\end{array}$ \\
\hline$T$ & $\begin{array}{c}-0.0014 \\
(-1.4)\end{array}$ & $\begin{array}{c}0.025^{\star * *} \\
(15.45)\end{array}$ & $\begin{array}{l}0.0037^{* * *} \\
(2.87)\end{array}$ & $\begin{array}{c}-0.0073^{\star * *} \\
(-5.87)\end{array}$ & $\begin{array}{l}0.0014^{\star \star} \\
(2.19)\end{array}$ \\
\hline \multicolumn{6}{|c|}{ Panel B: One-sided error term } \\
\hline$\eta$ & 0 & $\begin{array}{c}0.0032^{\star * *} \\
(3.36)\end{array}$ & $\begin{array}{c}-0.0191^{\star \star \star} \\
(-10.33)\end{array}$ & $\begin{array}{c}0.0716^{* \star *} \\
(7.60)\end{array}$ & $\begin{array}{c}0.0086^{* * *} \\
(7.76)\end{array}$ \\
\hline LLF & 240.18 & 304.87 & 624.00 & 333.00 & 1240.23 \\
\hline$\sigma^{2}=\sigma_{u}^{2}+\sigma_{v}^{2}$ & $\begin{array}{c}0.4682^{\star * \star} \\
(9.55)\end{array}$ & $\begin{array}{c}1.2846 \\
(1.33)\end{array}$ & $\begin{array}{c}0.2637^{* * *} \\
(3.02)\end{array}$ & $\begin{array}{l}0.01^{* * *} \\
(13.30)\end{array}$ & $\begin{array}{c}0.3369 * * \\
(2.38)\end{array}$ \\
\hline$\gamma=\sigma_{u}^{2} /\left(\sigma_{v}^{2}+\sigma_{u}^{2}\right)$ & $\begin{array}{c}0.9222^{* * *} \\
(117.75)\end{array}$ & $\begin{array}{c}0.9918^{* * *} \\
(146.59)\end{array}$ & $\begin{array}{c}0.9414^{* * *} \\
(48.01)\end{array}$ & $\begin{array}{l}0.023 \\
(0.89)\end{array}$ & $\begin{array}{c}0.9841^{* * *} \\
(144.37)\end{array}$ \\
\hline
\end{tabular}

Notes: The frontier specification for each region is based on the hypothesis tests as reported in Table B1 in Appendix B. LLF stands for log-likelihood function. Technical efficiency is time-invariant for Africa ( $\eta$ is set equal to zero for Africa). The numbers in parentheses are $t$-statistics. ${ }^{* * * \text { Significant }}$ at the $1 \%$; ** Significant at the $5 \%$; ${ }^{*}$ Significant at the $10 \%$. 


\section{Output Growth Decomposition with Input Quality Effects}

in East Asia, Latin America and the West, but negative and insignificant in Africa and negative and significant in South Asia. That is, positive technological change occurs in those regions where the average age of capital is negatively related to economic growth. This indicates that whenever the age of capital is significant and with the right sign, technology improves growth. The last four rows of Table 6 show the results related to the inefficiency term. Technical efficiency significantly improves in East Asia, South Asia and the West but significantly deteriorates in Latin America. In accordance with our stochastic frontier test results, Africa's technical efficiency is set so as not to vary with time. The estimated coefficients for $\gamma$ for Africa, East Asia, Latin America, South Asia and the West are, respectively, 0.92, $0.99,0.94,0.023$ and 0.98 . These results indicate that technical efficiency explains most of the error variations in Africa, East Asia, Latin America and the West, but does not explain much of the error term in South Asia.

One may argue that the age of physical capital is endogenous to the model, namely that it can be correlated with the error term. Few have addressed the issue of endogeneity in the production function in a stochastic frontier framework (Guan et al., 2009). One procedure to control for endogeneity is to estimate our inefficiency model by including lagged values of the variables (Christopoulos et al., 2015; Wang and Wong, 2012). Lagged values are less likely to be influenced by current shocks, for they are strongly correlated with the current variables, but not correlated with the residual. We therefore reran our five estimations with the age of capital lagged by one period. As the lagged age interacts with lagged capital, we also lag physical capital by one period. As reported in Table 7, results remain largely unchanged: the coefficient on the age of capital is still negative and significant in East Asia, Latin America and the West.

Table 8 reports the results for the technical efficiency estimates - means, standard deviations, and minimum and maximum values. South Asia possesses the highest average efficiency (0.89) while the West exhibits the lowest efficiency (0.55). ${ }^{10}$ South Africa dominates within Africa with the highest efficiency (0.95) while Uganda exhibits the lowest efficiency (0.10). In Latin America, Venezuela shows the highest efficiency (0.99) while Nicaragua shows the lowest efficiency (0.48). In the West, the average efficiency varies from the low of 0.25 in Cyprus to 0.99 in the United States. Finally, in East Asia the average efficiency varies from the low of 0.26 in China to 0.97 in Hong Kong. Most other East Asian countries exhibit low efficiencies as compared to Hong Kong, leading East Asia to exhibit the highest variability $(0.24)$.

To calculate the output elasticity of capital, we differentiate equation (14) with respect to the natural logarithm of capital to derive the output elasticity of capital:

$$
\frac{\partial \ln Y_{i t}}{\partial \ln K_{i t}}=\alpha_{1}+\alpha_{2} V_{i t}
$$

Similarly, the output elasticity of labor is:

$$
\frac{\partial \ln Y_{i t}}{\partial \ln L_{i t}}=\omega_{1}+\omega_{2} H_{i t}
$$

10. As technical efficiencies are determined relative to each region's most efficient country, one cannot compare average efficiencies among regions. 


\section{Y. R. Limam et al.}

Table 7 Endogeneity

\begin{tabular}{|c|c|c|c|c|c|}
\hline Variables & Africa & East Asia & Latin America & South Asia & West \\
\hline \multicolumn{6}{|c|}{ Panel A: Production function } \\
\hline Intercept & $\begin{array}{c}5.2658^{* * *} \\
(9.34)\end{array}$ & $\begin{array}{l}6.5215^{* * *} \\
(4.65)\end{array}$ & $\begin{array}{c}3.9362^{* * *} \\
(14.90)\end{array}$ & $\begin{array}{c}3.3954^{* * *} \\
(18.67)\end{array}$ & $\begin{array}{c}5.6861^{* * *} \\
(14.84)\end{array}$ \\
\hline $\ln K_{l a g}$ & $\begin{array}{c}0.6073^{* * *} \\
(28.06)\end{array}$ & $\begin{array}{c}0.3299^{\star * *} \\
(7.18)\end{array}$ & $\begin{array}{c}0.5448^{* * *} \\
(29.29)\end{array}$ & $\begin{array}{c}0.5587^{* * *} \\
(31.02)\end{array}$ & $\begin{array}{c}0.5518^{* * *} \\
(26.23)\end{array}$ \\
\hline $\ln L$ & $\begin{array}{c}0.3424^{* * *} \\
(5.33)\end{array}$ & $\begin{array}{c}0.6742^{* * *} \\
(5.39)\end{array}$ & $\begin{array}{c}0.5133^{* * *} \\
(22.82)\end{array}$ & $\begin{array}{c}0.4545^{* * *} \\
(27.32)\end{array}$ & $\begin{array}{c}0.3567^{* * *} \\
(13.36)\end{array}$ \\
\hline$V_{\text {lag }} \ln K_{\text {lag }}$ & $\begin{array}{c}0.0006^{* *} \\
(2.17)\end{array}$ & $\begin{array}{c}-0.0027^{* * *} \\
(-7.07)\end{array}$ & $\begin{array}{c}-0.0012^{\star * \star} \\
(-4.14)\end{array}$ & $\begin{array}{c}0.0015^{\star \star *} \\
(5.14)\end{array}$ & $\begin{array}{c}-0.0017^{* * *} \\
(-7.18)\end{array}$ \\
\hline$H \ln L$ & $\begin{array}{c}0.0129^{* * *} \\
(5.91)\end{array}$ & $\begin{array}{l}-0.0014 \\
(-0.69)\end{array}$ & $\begin{array}{c}0.0033 \\
(1.31)\end{array}$ & $\begin{array}{c}0.0184^{\star * *} \\
(8.66)\end{array}$ & $\begin{array}{c}0.0033^{* * *} \\
(4.55)\end{array}$ \\
\hline$T$ & $\begin{array}{c}-0.0023 \\
(-1.34)\end{array}$ & $\begin{array}{c}0.0261^{* * *} \\
(4.80)\end{array}$ & $\begin{array}{c}0.0024^{*} \\
(1.75)\end{array}$ & $\begin{array}{c}-0.0071^{* * *} \\
(-5.37)\end{array}$ & $\begin{array}{c}0.0022^{* * *} \\
(3.73)\end{array}$ \\
\hline \multicolumn{6}{|c|}{ Panel B: One-sided error term } \\
\hline$\eta$ & 0 & $\begin{array}{c}0.0044^{\star * *} \\
(3.81)\end{array}$ & $\begin{array}{c}-0.0203^{\star * *} \\
(-10.15)\end{array}$ & $\begin{array}{c}0.0766^{\star \star \star} \\
(6.77)\end{array}$ & $\begin{array}{l}0.0112^{* * *} \\
(8.55)\end{array}$ \\
\hline LLF & 228.60 & 276.86 & 545.67 & 315.83 & $1,155.72$ \\
\hline$\sigma^{2}=\sigma_{u}^{2}+\sigma_{v}^{2}$ & $\begin{array}{c}2.6751^{* * *} \\
(3.46)\end{array}$ & $\begin{array}{c}1.7611^{\star *} \\
(1.98)\end{array}$ & $\begin{array}{l}0.2528^{* * *} \\
\quad(3.08)\end{array}$ & $\begin{array}{c}0.0103^{\star * *} \\
(13.85)\end{array}$ & $\begin{array}{c}0.2041^{\star *} \\
(2.43)\end{array}$ \\
\hline$\gamma=\sigma_{u}^{2} /\left(\sigma_{v}^{2}+\sigma_{u}^{2}\right)$ & $\begin{array}{c}0.9863^{* * *} \\
(244.55)\end{array}$ & $\begin{array}{c}0.9933^{* * *} \\
(281.23)\end{array}$ & $\begin{array}{l}0.9301^{* * *} \\
(40.8)\end{array}$ & $\begin{array}{c}0.0138 \\
(0.81)\end{array}$ & $\begin{array}{c}0.9706^{* * *} \\
(77.71)\end{array}$ \\
\hline
\end{tabular}

Notes: The frontier specification for each region is based on the hypothesis tests as reported in Table B1 in Appendix B. The lag subscript stands for a lag of one period. LLF stands for log-likelihood function. Technical efficiency is time-invariant for Africa ( $\eta$ is set equal to zero for Africa). The numbers in parentheses are $t$-statistics. ${ }^{* * *}$ Significant at the $1 \%$; ${ }^{* *}$ Significant at the $5 \%$; ${ }^{*}$ Significant at the $10 \%$.

With different values of $V$ and $H$ over countries and over time, equations (17) and (18) do not allow the calculation of a single value for capital and labor elasticity for each region. Consequently, we calculate a range of output elasticities using the minimum and the maximum values of $V$ and $H$ in each region. Table 9

Table 8 Descriptive statistics of technical efficiency

\begin{tabular}{|c|c|c|c|c|c|}
\hline Region & Mean & SD & Minimum & Maximum & Sample size \\
\hline Africa & 0.58 & 0.21 & $\begin{array}{c}0.10 \\
\text { (Uganda) }\end{array}$ & $\begin{array}{c}0.95 \\
\text { (South Africa) }\end{array}$ & 30 \\
\hline East Asia & 0.69 & 0.24 & $\begin{array}{c}0.26 \\
\text { (China) }\end{array}$ & $\begin{array}{c}0.97 \\
\text { (Hong Kong) }\end{array}$ & 8 \\
\hline Latin America & 0.77 & 0.14 & $\begin{array}{c}0.48 \\
\text { (Nicaragua) }\end{array}$ & $\begin{array}{c}0.99 \\
\text { (Venezuela) }\end{array}$ & 21 \\
\hline South Asia & 0.89 & 0.10 & $\begin{array}{c}0.83 \\
\text { (India) }\end{array}$ & $\begin{array}{c}0.98 \\
\text { (Bangladesh) }\end{array}$ & 8 \\
\hline West & 0.55 & 0.16 & $\begin{array}{c}0.25 \\
\text { (Cyprus) }\end{array}$ & $\begin{array}{c}0.99 \\
\text { (U.S.) }\end{array}$ & 23 \\
\hline
\end{tabular}




\section{Output Growth Decomposition with Input Quality Effects}

Table 9 Capital and labor elasticities

\begin{tabular}{lccccc}
\hline Region & Mean & SD & Minimum & Maximum & Sample size \\
\hline \multicolumn{5}{c}{ Panel A: Elasticity of capital } \\
\hline Africa & 0.616 & 0.001 & 0.614 & 0.623 & 30 \\
East Asia & 0.408 & 0.004 & 0.400 & 0.421 & 8 \\
Latin America & 0.543 & 0.002 & 0.536 & 0.548 & 21 \\
South Asia & 0.583 & 0.002 & 0.579 & 0.590 & 8 \\
West & 0.642 & 0.002 & 0.638 & 0.647 & 23 \\
\hline & & Panel B: Elasticity of labor & & 30 \\
\hline Africa & 0.322 & 0.010 & 0.312 & 0.358 & 8 \\
East Asia & 0.549 & 0.005 & 0.538 & 0.557 & 23 \\
Latin America & 0.496 & 0.002 & 0.493 & 0.503 & 0.490 \\
South Asia & 0.457 & 0.010 & 0.442 & 0.233 & 23 \\
West & 0.225 & 0.004 & 0.217 &
\end{tabular}

lists the summary statistics for the output elasticities with respect to capital and labor. The capital elasticity is highest in the West and lowest in East Asia while labor elasticity is highest in East Asia and lowest in the West. Moreover, the variability of the labor elasticity exceeds that of the capital elasticity in all regions except in Latin America where both variabilities are equal.

We next decompose output growth into input growth, input quality change, technical efficiency change and technological change. The role of physical capital in economic growth is a controversial topic and is often linked to the level of development. The stochastic frontier framework that we adopt allows a better look at the components of output growth because it accounts for changes in efficiency. In addition, the model permits the distinction between the quantity and the quality of the inputs. The growth of output equals the total derivative of equation (14) with respect to time. Consequently, equation (14) in growth rates becomes:

$$
\frac{\dot{\hat{Y}}}{\widehat{Y}}=\left(\alpha_{1}+\alpha_{2} V\right) \frac{\dot{K}}{K}+\left(\omega_{1}+\omega_{2} H\right) \frac{\dot{L}}{L}+\alpha_{2} V \ln K \frac{\dot{V}}{V}+\omega_{2} H \ln L \frac{\dot{H}}{H}+\frac{\dot{T} E}{T E}+\xi,
$$

where dots over variables represent time derivatives and $\widehat{Y}$ is the estimated value of $Y$. We approximate the growth rate of variable $X$ by the natural logarithmic difference between $t$ and $t-1$. That is,

$$
\frac{\dot{X}}{X}=\ln X_{i t}-\ln X_{i t-1}, \quad \text { where } X=Y, K, L, V, H \text { and } T E .
$$

Equation (19) illustrates that the percentage change in output includes: (i) the change in the units of capital; (ii) the change in the units of labor; (iii) the change in the average age of capital; (iv) the change in the mean years of education; (v) the efficiency change and (vi) the technological change.

The third and fourth terms on the right hand side of equation (19) capture the part of output growth explained by changes in the quality of inputs. The model permits output to change even if no change in the quantity of capital and labor occurs. For example, higher output growth can occur without higher labor 


\section{Y. R. Limam et al.}

Table 10 Output growth decomposition by region (share in total growth)

\begin{tabular}{lcccccccccc}
\hline \multicolumn{1}{c}{$\begin{array}{c}\text { Variables } \\
\text { Region }\end{array}$} & $\hat{Y}$ & $K$ & $L$ & $V$ & $H$ & $T E$ & $T$ & $K+L$ & $V+H$ & $T F P$ \\
\hline Africa & 100 & 67.52 & 25.75 & 0.55 & 10.49 & 0.00 & -4.30 & 93.27 & 11.03 & 6.73 \\
East Asia & 100 & 43.03 & 19.84 & -2.02 & -3.86 & 2.34 & 40.68 & 62.87 & -5.89 & 37.13 \\
Latin America & 100 & 62.28 & 42.23 & -2.22 & 2.91 & -17.11 & 11.91 & 104.52 & 0.69 & -4.52 \\
South Asia & 100 & 59.75 & 24.98 & -0.14 & 14.46 & 17.58 & -16.62 & 84.73 & 14.32 & 15.27 \\
West & 100 & 68.28 & 8.00 & -1.02 & 4.37 & 16.28 & 4.12 & 76.25 & 3.35 & 23.75 \\
\hline
\end{tabular}

growth, if the human capital embodied in labor increases. Similarly, higher output growth can occur without higher capital growth, if the capital gets younger. ${ }^{11}$ We calculate the different components of output growth for the five regions.

Table 10 reports the results of the output growth decomposition by region over the entire period as share in total growth. (Table B4 in Appendix B presents the decomposition by decade and by region.) Results indicate that physical capital, labor, technical efficiency and technological change all contribute importantly to output growth. Their strengths, however, vary across regions. The contribution to output growth of physical capital achieves its largest values in the West, where it accounts for $68.28 \%$ of total output growth, and its lowest value in East Asia where it explains only $43.03 \%$ of output growth. Meanwhile, the contribution of labor to output growth achieves its highest value in Latin America where it accounts for $42.23 \%$ of total output growth, and its lowest values in the West where it explains $8 \%$ of total output growth. In all regions, the findings show that the contribution of physical capital to output growth far exceeds that of labor. Labor 'quantity appears to be a weak foundation on which to build strong growth' (Gapinski, 1999, p. 125).

Regarding technical efficiency, results show that technical efficiency change exhibits the largest effect on output growth in South Asia at 17.58\%, and the smallest effect in Latin America at $-17.11 \%$. When one considers the contribution of technological change to growth, we find that technological change possesses the highest share in total output growth in East Asia at $40.68 \%$, and the lowest in South Asia at $-16.62 \%$. In addition to its negative effect in South Asia, technological change seems to affect growth negatively in Africa as well. These results correspond with those of Kerekes (2011), which argues that technological change contributes to growth in high and middle income countries, but not in low income countries.

Narrowing our focus within the output growth determinants to include input quality, we notice that both the age of physical capital and human capital affect growth in the expected direction in four out of the five regions. The share of the age of capital in growth is negative in all regions except in Africa (the higher the average age of physical capital, the lower the growth of output) while the share of human capital in total growth is positive in all regions except in East Asia.

11. These assertions implicitly assume that the effects of the age of capital and the educational attainment achieve their expected outcomes. 


\section{Output Growth Decomposition with Input Quality Effects}

The results suggest that human capital exerts a bigger effect on growth than the age of capital in most regions indicating that the quality of labor takes over the quality of physical capital in most regions. Take note, however, that it is in South Asia that the quality of inputs has the highest positive effects on growth (column $V+H$ in Table 10). Taking a closer look at input quality reveals that quantity exceeds quality for both capital and labor. To illustrate, in the West, for the entire sample, the total output growth equals $3.40 \%$ over the period (Table B4). This rate includes an increase in physical capital of $2.32 \%$, which constitutes $68.25 \%$ of total output growth, and the age of capital reduces growth by $0.03 \%$, or by $-1.02 \%$ of total output growth. Moreover, in the West, labor explains $8 \%$ of total output growth, while the quality of labor increases growth by $4.37 \%$. Gapinski (1999) correlates well with our results. He finds that, with the exception of Argentina, Brazil, Mexico, and Venezuela (his Latin Rim region), all other regions in his analysis rank international trade, capital quantity, and labor quantity as the top three determinants of output growth while capital quality and labor quality equal the bottom two forces, but by a wider margin for capital.

Whether factor accumulation or TFP growth contributes more to output growth remains perhaps the most controversial question in growth theory. Solow (1956) argues that the residual and not factor accumulation accounts for the bulk of output growth in the United States. Easterly and Levine (2001) and King and Levine (1994) also find that the residual accounts for most of the income and output growth differences across countries. Kumar and Russell (2002) and Nissan and Niroomand (2006) instead argue in favor of factor accumulation. To evaluate the role of TFP in output growth, we calculate the share of TFP growth in total output growth for each region as the difference between the rate of change of real product and the rate of growth of inputs. Applying this definition to equation (19), the change in TFP can be calculated as follows:

$$
\frac{T \dot{F P}}{T F P}=\frac{\dot{\hat{Y}}}{\widehat{Y}}-\left[\left(\alpha_{1}+\alpha_{2} V\right) \frac{\dot{K}}{K}+\left(\omega_{1}+\omega_{2} H\right) \frac{\dot{L}}{L}\right] .
$$

The last column of Table 10 shows the growth in TFP and its contribution to output growth. The share of TFP in growth reaches the highest percentages in East Asia and the West where TFP growth contributes $37.13 \%$ and $23.75 \%$ of total output growth while it reaches its lowest in Latin America and Africa with contributions to growth of $-4.52 \%$ and $6.73 \%$, respectively. Comparing the last column of Table $10(T F P)$ to the third $(K)$, we notice that capital accumulation overtakes TFP by far in all regions. This result supports the claim that it is physical capital accumulation and not TFP that explains most of growth.

\section{CONCLUSION}

This article contributes to the growth literature by examining the relative effects of factor accumulation and TFP improvement on output growth, taking into account the quality of inputs. We consider that the productivity of physical capital increases the younger is the capital; while the productivity of labor is higher 


\section{Y. R. Limam et al.}

the more educated workers are. We estimate the average age of physical capital for 90 countries (grouped into five regions) and over the period 1960-2007. We find that the role of the age of the physical capital stock is not irrelevant to pinpoint productivity: stochastic frontier estimation reveals that the coefficient on the average age of physical capital proves negative and significant in three out of five regions. The negative effect of the average age of physical capital indicates that in these regions older capital exhibits lower productivity. Human capital possesses a positive and significant effect in all regions except in East Asia. The negative sign on human capital in East Asia probably reflects the sharp decline in the average years of education in this group in the years 2000 .

The decomposition of output growth demonstrates that, in all regions, physical capital growth proves more important than either the improved quality of factors or TFP growth in explaining output growth. This result is in line with the claim that physical capital accumulation is the main driver of growth. Physical capital shows the highest share in the West, where it explains about $68.28 \%$ of total growth, and the lowest in East Asia, where it explains about $43.03 \%$ of output growth. Technological change exerts the highest effect on growth in East Asia, where it explains $40.68 \%$ of total growth, and the lowest in South Asia, where it contributes negatively to growth with a share in total growth of $-16.62 \%$.

Our growth decomposition shows that the age of physical capital decreases growth in four out of five regions (even if this effect is relatively small). This result hints that the old age of physical capital in these regions can be an obstacle to growth and that investing in newer physical capital that embeds more recent technology would enhance growth and productivity. Moreover, Africa and South Asia are the only two regions where the contribution of technological change to total output growth is negative. These are also the regions with the lowest average level of education. This suggests that there is an absence of human capital to successfully adopt and absorb foreign technology. It seems sensible for countries in these two regions to invest more in education if they want foreign technology to translate into growth. At the same time, this is not to say that other factors do not influence growth and TFP. For example, the expansion of our analysis of input quality to also include the institutional matrix (e.g. Acemoglu et al., 2005) is an important area of future research. 


\section{Output Growth Decomposition with Input Quality Effects}

\section{APPENDIX A: SAMPLE}

\section{LIST OF COUNTRIES BY REGION (90 COUNTRIES TOTAL)}

Africa (30 countries): Algeria, Benin, Botswana, Burundi, Central African Republic, Congo (Democratic Republic of), Côte d'Ivoire, Egypt, Gabon, Gambia (The), Ghana, Kenya, Lesotho, Malawi, Mali, Mauritania, Mauritius, Morocco, Mozambique, Namibia, Niger, Rwanda, Senegal, Sierra Leone, South Africa, Tanzania, Tunisia, Uganda, Zambia and Zimbabwe.

East Asia (8 countries): China, Hong Kong, Japan, Korea (Republic of), Malaysia, Singapore, Taiwan and Thailand.

Latin America (21 countries): Argentina, Bolivia, Brazil, Chile, Colombia, Costa Rica, Dominican Republic, Ecuador, El Salvador, Guatemala, Haiti, Honduras, Jamaica, Mexico, Nicaragua, Panama, Paraguay, Peru, Trinidad and Tobago, Uruguay and Venezuela.

South Asia (8 countries): Bangladesh, India, Indonesia, Nepal, Pakistan, Papua New Guinea, Philippines and Sri Lanka.

West (23 countries): Australia, Austria, Belgium, Canada, Cyprus, Denmark, Finland, France, Greece, Iceland, Ireland, Israel, Italy, Luxemburg, the Netherlands, New Zealand, Norway, Portugal, Spain, Sweden, Switzerland, United Kingdom and United States.

\section{APPENDIX B: ADDITIONAL TABLES}

Table B1 Results of hypothesis testing

\begin{tabular}{|c|c|c|c|}
\hline Region & $\chi^{2}$-statistic & $\chi_{0.99}^{2}$ & Decision \\
\hline \multicolumn{4}{|c|}{ Panel A: Global vs. regional frontier; $H_{0}$ : Regions exhibit different production frontiers } \\
\hline - & $-2,330$ & 42.98 & Fail to reject $\mathrm{H}_{0}$ \\
\hline \multicolumn{4}{|c|}{ Panel B: Stochastic frontier vs. OLS; $H_{0}: \gamma=\mu=\eta=0$} \\
\hline Africa & $2,177.43$ & 11.34 & Reject $\mathrm{H}_{0}$ \\
\hline East Asia & 386.19 & 11.34 & Reject $\mathrm{H}_{0}$ \\
\hline Latin America & 937.79 & 11.34 & Reject $\mathrm{H}_{0}$ \\
\hline South Asia & 162.32 & 11.34 & Reject $\mathrm{H}_{0}$ \\
\hline West & $1,034.94$ & 11.34 & Reject $\mathrm{H}_{0}$ \\
\hline \multicolumn{4}{|c|}{ Panel C: Half-normal vs. Truncated normal; $H_{O}: \mu=0$} \\
\hline Africa & -0.04 & 6.63 & Fail to Reject $\mathrm{H}_{0}$ \\
\hline East Asia & 49.74 & 6.63 & Reject $\mathrm{H}_{0}$ \\
\hline Latin America & 0.68 & 6.63 & Fail to reject $\mathrm{H}_{0}$ \\
\hline South Asia & 0.66 & 6.63 & Fail to reject $\mathrm{H}_{0}$ \\
\hline West & -4 & 6.63 & Fail to reject $\mathrm{H}_{0}$ \\
\hline
\end{tabular}


Table B1. Continued

\begin{tabular}{lccc}
\hline Region & $\chi^{2}$-statistic & $\chi_{0.99}^{2}$ & Decision \\
\hline & Panel D: Time varying vs. Time invarying; $H_{O}: \eta=0$ & \\
\hline Africa & 3.48 & 6.63 & Fail to reject $\mathrm{H}_{0}$ \\
East Asia & 70.62 & 6.63 & Reject $\mathrm{H}_{0}$ \\
Latin America & 101.58 & 6.63 & Reject $\mathrm{H}_{0}$ \\
South Asia & 66 & 6.63 & Reject $\mathrm{H}_{0}$ \\
West & 144.46 & 6.63 & Reject $\mathrm{H}_{0}$ \\
\hline
\end{tabular}

Table B2 Unit-root test

\begin{tabular}{|c|c|c|c|c|c|}
\hline $\begin{array}{l}\text { Variables } \\
\text { Region }\end{array}$ & $\ln Y$ & $\ln K$ & $\ln L$ & $V \ln K$ & $H \ln L$ \\
\hline \multicolumn{6}{|c|}{ Panel A: Variables in levels } \\
\hline Africa & $\begin{array}{l}-0.380 \\
(0.352)\end{array}$ & $\begin{array}{l}-2.850 \\
(0.002)\end{array}$ & $\begin{array}{l}-0.377 \\
(0.353)\end{array}$ & $\begin{array}{l}-3.450 \\
(0.000)\end{array}$ & $\begin{array}{l}-0.867 \\
(0.807)\end{array}$ \\
\hline East Asia & $\begin{array}{c}3.726 \\
(0.999)\end{array}$ & $\begin{array}{l}-0.030 \\
(0.488)\end{array}$ & $\begin{array}{c}6.222 \\
(1.000)\end{array}$ & $\begin{array}{l}-0.377 \\
(0.353)\end{array}$ & $\begin{array}{l}-0.803 \\
(0.211)\end{array}$ \\
\hline Latin America & $\begin{array}{c}0.396 \\
(0.654)\end{array}$ & $\begin{array}{l}-2.132 \\
(0.017)\end{array}$ & $\begin{array}{c}3.607 \\
(1.000)\end{array}$ & $\begin{array}{l}-3.605 \\
(0.000)\end{array}$ & $\begin{array}{l}-1.156 \\
(0.124)\end{array}$ \\
\hline South Asia & $\begin{array}{c}1.518 \\
(0.935)\end{array}$ & $\begin{array}{c}2.936 \\
(0.998)\end{array}$ & $\begin{array}{c}0.473 \\
(0.682)\end{array}$ & $\begin{array}{l}-1.487 \\
(0.069)\end{array}$ & $\begin{array}{l}-1.360 \\
(0.913)\end{array}$ \\
\hline West & $\begin{array}{l}-2.766 \\
(0.003)\end{array}$ & $\begin{array}{l}-3.250 \\
(0.001)\end{array}$ & $\begin{array}{c}2.074 \\
(0.981)\end{array}$ & $\begin{array}{l}-1.992 \\
(0.023)\end{array}$ & $\begin{array}{l}-0.183 \\
(0.428)\end{array}$ \\
\hline \multicolumn{6}{|c|}{ Panel B: Variables in first difference } \\
\hline Africa & -33.360 & -5.932 & -6.923 & -6.040 & $\begin{array}{c}1.394 \\
(0.918)\end{array}$ \\
\hline East Asia & -11.709 & $\begin{array}{l}-1.972 \\
(0.024)\end{array}$ & -9.692 & $\begin{array}{l}-2.198 \\
(0.014)\end{array}$ & $\begin{array}{l}-2.516 \\
(0.006)\end{array}$ \\
\hline Latin America & -15.539 & $\begin{array}{l}-2.934 \\
(0.002)\end{array}$ & -14.983 & -3.645 & $\begin{array}{c}0.959 \\
(0.831)\end{array}$ \\
\hline South Asia & -16.343 & $\begin{array}{l}-2.393 \\
(0.008)\end{array}$ & -7.812 & $\begin{array}{l}-2.677 \\
(0.004)\end{array}$ & $\begin{array}{l}-3.189 \\
(0.001)\end{array}$ \\
\hline West & -18.606 & -3.566 & -17.041 & -4.295 & -4.944 \\
\hline
\end{tabular}

Notes: The Im et al. (2003) unit-root test has $\mathrm{H}_{0}$ : non-stationarity in the series. The number in parentheses corresponds to the $p$-value. For Panel B, except for those reported in parentheses, the $p$-values are all $<0.001$. 


\section{Output Growth Decomposition with Input Quality Effects}

Table B3 Cointegration test

\begin{tabular}{|c|c|c|}
\hline $\begin{array}{l}\text { Hypothesized number of } \\
\text { cointegrated equations }\end{array}$ & $\begin{array}{l}\text { Fisher statistic } \\
\text { (from trace test) }\end{array}$ & $\begin{array}{l}\text { Fisher statistic (from } \\
\text { max-eigenvalue test) }\end{array}$ \\
\hline \multicolumn{3}{|c|}{ Panel A: Africa } \\
\hline None & 837.7 & 445.2 \\
\hline At most 1 & 455.2 & 231.8 \\
\hline At most 2 & 252.9 & 154.0 \\
\hline At most 3 & 153.7 & 112.2 \\
\hline At most 4 & $93.66(0.0035)$ & $93.66(0.0035)$ \\
\hline \multicolumn{3}{|c|}{ Panel B: East Asia } \\
\hline None & 279.8 & 155.7 \\
\hline At most 1 & 150.2 & 75.54 \\
\hline At most 2 & 86.57 & 47.93 \\
\hline At most 3 & 50.50 & $35.07(0.0039)$ \\
\hline At most 4 & $30.96(0.0136)$ & $30.96(0.0136)$ \\
\hline
\end{tabular}

Panel C: Latin America

\begin{tabular}{lcc}
\hline None & 523.6 & 293.4 \\
At most 1 & 272.5 & 134.5 \\
At most 2 & 163.9 & 83.58 \\
At most 3 & 108.5 & $72.73(0.0023)$ \\
At most 4 & $74.62(0.0014)$ & $74.62(0.0014)$ \\
\hline & Panel D: South Asia & \\
\hline None & 173.5 & 93.27 \\
At most 1 & 94.46 & $43.54(0.0002)$ \\
At most 2 & 59.02 & $35.47(0.0034)$ \\
At most 3 & $34.43(0.0048)$ & $23.77(0.0946)$ \\
At most 4 & $24.18(0.0856)$ & $24.18(0.0856)$ \\
\hline & Panel E: West & \\
\hline None & 669.1 & 165.5 \\
At most 1 & 344.4 & 91.71 \\
At most 2 & 208.0 & 86.64 \\
At most 3 & 135.1 & \\
At most 4 & 86.64 &
\end{tabular}

Notes: Results are from Johansen Fisher Panel Cointegration Test. Probabilities are computed using asymptotic Chi-square distribution. Except for those reported in parentheses, the $p$-values are all $<0.001$. 
Table B4 Output growth decomposition by decade and by region in percent (share in total growth in parentheses)

\begin{tabular}{|c|c|c|c|c|c|c|c|c|}
\hline Year & $\frac{\dot{\hat{Y}}}{\widehat{\widehat{Y}}}$ & $\left(\alpha_{1}+\alpha_{2} V\right) \frac{\dot{K}}{K}$ & $\left(\omega_{1}+\omega_{2} H\right) \frac{\dot{L}}{L}$ & $\alpha_{2} V \ln K \frac{\dot{V}}{V}$ & $\omega_{2} H \ln L \frac{\dot{H}}{H}$ & $\frac{\dot{T E}}{T E}$ & $\xi$ & $\frac{T \dot{T F P}}{T F P}$ \\
\hline \multicolumn{9}{|c|}{ Panel A: Africa } \\
\hline $60-69$ & $\begin{array}{c}2.35 \\
(100)\end{array}$ & $\begin{array}{c}1.61 \\
(68.60)\end{array}$ & $\begin{array}{c}0.62 \\
(26.48)\end{array}$ & $\begin{array}{c}0.04 \\
(1.56)\end{array}$ & $\begin{array}{c}0.22 \\
(9.18)\end{array}$ & $\begin{array}{c}0.00 \\
(0.00)\end{array}$ & $\begin{array}{l}-0.137 \\
(-5.83)\end{array}$ & $\begin{array}{c}0.12 \\
(4.92)\end{array}$ \\
\hline $70-79$ & $\begin{array}{c}4.37 \\
(100)\end{array}$ & $\begin{array}{c}3.48 \\
(79.64)\end{array}$ & $\begin{array}{c}0.80 \\
(18.34)\end{array}$ & $\begin{array}{c}-0.08 \\
(-1.88)\end{array}$ & $\begin{array}{c}0.31 \\
(7.03)\end{array}$ & $\begin{array}{c}0.00 \\
(0.00)\end{array}$ & $\begin{array}{l}-0.137 \\
(-3.13)\end{array}$ & $\begin{array}{c}0.09 \\
(2.02)\end{array}$ \\
\hline $80-89$ & $\begin{array}{c}3.43 \\
(100)\end{array}$ & $\begin{array}{c}1.99 \\
(58.00)\end{array}$ & $\begin{array}{c}0.95 \\
(27.85)\end{array}$ & $\begin{array}{c}0.11 \\
(3.14)\end{array}$ & $\begin{array}{c}0.51 \\
(15.00)\end{array}$ & $\begin{array}{c}0.00 \\
(0.00)\end{array}$ & $\begin{array}{l}-0.137 \\
(-3.99)\end{array}$ & $\begin{array}{c}0.48 \\
(14.16)\end{array}$ \\
\hline $90-99$ & $\begin{array}{c}2.71 \\
(100)\end{array}$ & $\begin{array}{c}1.51 \\
(55.70)\end{array}$ & $\begin{array}{c}0.91 \\
(33.60)\end{array}$ & $\begin{array}{c}0.07 \\
(2.59)\end{array}$ & $\begin{array}{c}0.36 \\
(13.15)\end{array}$ & $\begin{array}{c}0.00 \\
(0.00)\end{array}$ & $\begin{array}{l}-0.137 \\
(-5.04)\end{array}$ & $\begin{array}{c}0.29 \\
(10.70)\end{array}$ \\
\hline $00-07$ & $\begin{array}{c}3.02 \\
(100)\end{array}$ & $\begin{array}{c}2.14 \\
(70.56)\end{array}$ & $\begin{array}{c}0.80 \\
(26.47)\end{array}$ & $\begin{array}{c}-0.05 \\
(-1.50)\end{array}$ & $\begin{array}{c}0.27 \\
(8.99)\end{array}$ & $\begin{array}{c}0.00 \\
(0.00)\end{array}$ & $\begin{array}{l}-0.137 \\
(-4.51)\end{array}$ & $\begin{array}{c}0.09 \\
(2.97)\end{array}$ \\
\hline $\begin{array}{l}\text { Average } \\
60-07\end{array}$ & $\begin{array}{c}3.18 \\
(100)\end{array}$ & $\begin{array}{c}2.15 \\
(67.52)\end{array}$ & $\begin{array}{c}0.82 \\
(25.75)\end{array}$ & $\begin{array}{c}0.02 \\
(0.55)\end{array}$ & $\begin{array}{c}0.33 \\
(10.49)\end{array}$ & $\begin{array}{c}0.00 \\
(0.00)\end{array}$ & $\begin{array}{l}-0.137 \\
(-4.30)\end{array}$ & $\begin{array}{c}0.21 \\
(6.37)\end{array}$ \\
\hline \multicolumn{9}{|c|}{ Panel B: East Asia } \\
\hline $60-69$ & $\begin{array}{c}5.72 \\
(100)\end{array}$ & $\begin{array}{c}1.77 \\
(30.85)\end{array}$ & $\begin{array}{c}1.45 \\
(25.36)\end{array}$ & $\begin{array}{l}0.007 \\
(0.13)\end{array}$ & $\begin{array}{c}-0.15 \\
(-2.66)\end{array}$ & $\begin{array}{c}0.15 \\
(2.67)\end{array}$ & $\begin{array}{c}2.50 \\
(43.64)\end{array}$ & $\begin{array}{c}2.51 \\
(43.78)\end{array}$ \\
\hline $70-79$ & $\begin{array}{l}8.26 \\
(100)\end{array}$ & $\begin{array}{c}3.60 \\
(43.55)\end{array}$ & $\begin{array}{c}1.68 \\
(20.28)\end{array}$ & $\begin{array}{c}0.61 \\
(7.46)\end{array}$ & $\begin{array}{c}-0.28 \\
(-3.34)\end{array}$ & $\begin{array}{c}0.15 \\
(1.80)\end{array}$ & $\begin{array}{c}2.50 \\
(30.25)\end{array}$ & $\begin{array}{c}2.99 \\
(36.16)\end{array}$ \\
\hline $80-89$ & $\begin{array}{c}6.66 \\
(100)\end{array}$ & $\begin{array}{c}3.05 \\
(45.80)\end{array}$ & $\begin{array}{c}1.36 \\
(20.50)\end{array}$ & $\begin{array}{c}-0.17 \\
(-2.57)\end{array}$ & $\begin{array}{c}-0.23 \\
(-3.40)\end{array}$ & $\begin{array}{c}0.14 \\
(2.15)\end{array}$ & $\begin{array}{c}2.50 \\
(37.52)\end{array}$ & $\begin{array}{c}2.24 \\
(33.70)\end{array}$ \\
\hline $90-99$ & $\begin{array}{c}6.32 \\
(100)\end{array}$ & $\begin{array}{c}3.22 \\
(51.02)\end{array}$ & $\begin{array}{c}0.91 \\
(14.38)\end{array}$ & $\begin{array}{c}-0.11 \\
(-1.76)\end{array}$ & $\begin{array}{c}-0.34 \\
(-5.41)\end{array}$ & $\begin{array}{c}0.14 \\
(2.20)\end{array}$ & $\begin{array}{c}2.50 \\
(39.58)\end{array}$ & $\begin{array}{c}2.19 \\
(34.60)\end{array}$ \\
\hline $00-07$ & $\begin{array}{c}3.76 \\
(100)\end{array}$ & $\begin{array}{c}1.58 \\
(42.14)\end{array}$ & $\begin{array}{c}0.69 \\
(18.40)\end{array}$ & $\begin{array}{c}-0.96 \\
(-25.64)\end{array}$ & $\begin{array}{c}-0.19 \\
(-5.03)\end{array}$ & $\begin{array}{c}0.13 \\
(3.59)\end{array}$ & $\begin{array}{c}2.50 \\
(66.53)\end{array}$ & $\begin{array}{c}1.48 \\
(39.46)\end{array}$ \\
\hline $\begin{array}{l}\text { Average } \\
60-07\end{array}$ & $\begin{array}{c}6.15 \\
(100)\end{array}$ & $\begin{array}{c}2.64 \\
(43.03)\end{array}$ & $\begin{array}{c}1.22 \\
(19.84)\end{array}$ & $\begin{array}{l}-0.12 \\
(-2.02)\end{array}$ & $\begin{array}{c}-0.24 \\
(-3.86)\end{array}$ & $\begin{array}{c}0.14 \\
(2.34)\end{array}$ & $\begin{array}{c}2.50 \\
(40.68)\end{array}$ & $\begin{array}{c}2.28 \\
(37.13)\end{array}$ \\
\hline \multicolumn{9}{|c|}{ Panel C: Latin America } \\
\hline $60-69$ & $\begin{array}{c}3.38 \\
(100)\end{array}$ & $\begin{array}{c}2.10 \\
(62.26)\end{array}$ & $\begin{array}{c}1.20 \\
(35.40)\end{array}$ & $\begin{array}{l}-0.006 \\
(-0.18)\end{array}$ & $\begin{array}{c}0.07 \\
(2.02)\end{array}$ & $\begin{array}{c}-0.35 \\
(-10.45)\end{array}$ & $\begin{array}{c}0.37 \\
(10.94)\end{array}$ & $\begin{array}{c}0.08 \\
(2.33)\end{array}$ \\
\hline $70-79$ & $\begin{array}{c}4.77 \\
(100)\end{array}$ & $\begin{array}{c}3.10 \\
(65.04)\end{array}$ & $\begin{array}{c}1.39 \\
(29.10)\end{array}$ & $\begin{array}{c}0.23 \\
(4.83)\end{array}$ & $\begin{array}{c}0.11 \\
(2.22)\end{array}$ & $\begin{array}{c}-0.43 \\
(-8.95)\end{array}$ & $\begin{array}{c}0.37 \\
(7.74)\end{array}$ & $\begin{array}{c}0.28 \\
(5.86)\end{array}$ \\
\hline 80-89 & $\begin{array}{c}1.98 \\
(100)\end{array}$ & $\begin{array}{c}1.29 \\
(64.77)\end{array}$ & $\begin{array}{c}1.27 \\
(63.87)\end{array}$ & $\begin{array}{c}-0.52 \\
(-25.98)\end{array}$ & $\begin{array}{c}0.09 \\
(4.75)\end{array}$ & $\begin{array}{c}-0.52 \\
(-26.06)\end{array}$ & $\begin{array}{c}0.37 \\
(18.64)\end{array}$ & $\begin{array}{c}-0.57 \\
(-28.64)\end{array}$ \\
\hline $90-99$ & $\begin{array}{c}3.05 \\
(100)\end{array}$ & $\begin{array}{c}1.72 \\
(56.21)\end{array}$ & $\begin{array}{c}1.45 \\
(47.36)\end{array}$ & $\begin{array}{c}0.05 \\
(1.57)\end{array}$ & $\begin{array}{c}0.1 \\
(3.23)\end{array}$ & $\begin{array}{c}-0.62 \\
(-20.48)\end{array}$ & $\begin{array}{c}0.37 \\
(12.12)\end{array}$ & $\begin{array}{l}-0.11 \\
(-3.57)\end{array}$ \\
\hline $00-07$ & $\begin{array}{c}2.34 \\
(100)\end{array}$ & $\begin{array}{c}1.46 \\
(62.50)\end{array}$ & $\begin{array}{c}1.26 \\
(53.84)\end{array}$ & $\begin{array}{c}-0.10 \\
(-4.38)\end{array}$ & $\begin{array}{c}0.08 \\
(3.61)\end{array}$ & $\begin{array}{c}-0.73 \\
(-31.37)\end{array}$ & $\begin{array}{c}0.37 \\
(15.80)\end{array}$ & $\begin{array}{c}-0.38 \\
(-16.34)\end{array}$ \\
\hline $\begin{array}{l}\text { Average } \\
60-07\end{array}$ & $\begin{array}{c}3.11 \\
(100)\end{array}$ & $\begin{array}{c}1.94 \\
(62.28)\end{array}$ & $\begin{array}{c}1.31 \\
(42.23)\end{array}$ & $\begin{array}{c}-0.07 \\
(-2.22)\end{array}$ & $\begin{array}{c}0.09 \\
(2.91)\end{array}$ & $\begin{array}{c}-0.53 \\
(-17.11)\end{array}$ & $\begin{array}{c}0.37 \\
(11.91)\end{array}$ & $\begin{array}{c}-0.14 \\
(-4.52)\end{array}$ \\
\hline
\end{tabular}


Output Growth Decomposition with Input Quality Effects

Table B4 Continued

\begin{tabular}{|c|c|c|c|c|c|c|c|c|}
\hline Year & $\frac{\hat{\hat{Y}}}{\widehat{Y}}$ & $\left(\alpha_{1}+\alpha_{2} V\right) \frac{\dot{K}}{K}$ & $\left(\omega_{1}+\omega_{2} H\right) \frac{\dot{L}}{L}$ & $\alpha_{2} V \ln K \frac{\dot{V}}{V}$ & $\omega_{2} H \ln L \frac{\dot{H}}{H}$ & $\frac{\dot{T E}}{T E}$ & $\xi$ & $\frac{T \dot{F P}}{T F P}$ \\
\hline \multicolumn{9}{|c|}{ Panel D: South Asia } \\
\hline $60-69$ & $\begin{array}{c}4.45 \\
(100)\end{array}$ & $\begin{array}{c}1.59 \\
(39.65)\end{array}$ & $\begin{array}{c}0.90 \\
(22.35)\end{array}$ & $\begin{array}{c}0.24 \\
(6.03)\end{array}$ & $\begin{array}{c}0.44 \\
(10.86)\end{array}$ & $\begin{array}{c}2.02 \\
(39.32)\end{array}$ & $\begin{array}{c}-0.73 \\
(-18.67)\end{array}$ & $\begin{array}{c}1.97 \\
(38.00)\end{array}$ \\
\hline $70-79$ & $\begin{array}{c}4.76 \\
(100)\end{array}$ & $\begin{array}{c}3.20 \\
(70.44)\end{array}$ & $\begin{array}{c}1.06 \\
(23.33)\end{array}$ & $\begin{array}{c}-0.37 \\
(-8.24)\end{array}$ & $\begin{array}{c}0.62 \\
(13.57)\end{array}$ & $\begin{array}{c}0.99 \\
(16.97)\end{array}$ & $\begin{array}{c}-0.73 \\
(-16.08)\end{array}$ & $\begin{array}{c}0.50 \\
(6.21)\end{array}$ \\
\hline $80-89$ & $\begin{array}{c}4.83 \\
(100)\end{array}$ & $\begin{array}{c}3.05 \\
(64.64)\end{array}$ & $\begin{array}{c}1.22 \\
(25.77)\end{array}$ & $\begin{array}{c}0.01 \\
(0.22)\end{array}$ & $\begin{array}{c}0.80 \\
(16.85)\end{array}$ & $\begin{array}{c}0.48 \\
(7.98)\end{array}$ & $\begin{array}{c}-0.73 \\
(-15.47)\end{array}$ & $\begin{array}{c}0.56 \\
(9.58)\end{array}$ \\
\hline 90-99 & $\begin{array}{c}3.99 \\
(100)\end{array}$ & $\begin{array}{c}2.69 \\
(68.23)\end{array}$ & $\begin{array}{c}1.11 \\
(28.12)\end{array}$ & $\begin{array}{c}0.05 \\
(1.17)\end{array}$ & $\begin{array}{c}0.64 \\
(16.33)\end{array}$ & $\begin{array}{c}0.24 \\
(4.67)\end{array}$ & $\begin{array}{c}-0.73 \\
(-18.54)\end{array}$ & $\begin{array}{c}0.20 \\
(3.64)\end{array}$ \\
\hline $00-07$ & $\begin{array}{c}3.93 \\
(100)\end{array}$ & $\begin{array}{c}2.60 \\
(66.07)\end{array}$ & $\begin{array}{c}1.21 \\
(30.69)\end{array}$ & $\begin{array}{c}0.05 \\
(1.15)\end{array}$ & $\begin{array}{c}0.68 \\
(17.42)\end{array}$ & $\begin{array}{c}0.13 \\
(3.24)\end{array}$ & $\begin{array}{c}-0.73 \\
(-18.57)\end{array}$ & $\begin{array}{c}0.13 \\
(3.24)\end{array}$ \\
\hline $\begin{array}{l}\text { Average } \\
60-07\end{array}$ & $\begin{array}{l}4.39 \\
(100)\end{array}$ & $\begin{array}{c}2.62 \\
(59.75)\end{array}$ & $\begin{array}{c}1.10 \\
(24.98)\end{array}$ & $\begin{array}{c}-0.01 \\
(-0.14)\end{array}$ & $\begin{array}{c}0.63 \\
(14.46)\end{array}$ & $\begin{array}{c}0.77 \\
(17.58)\end{array}$ & $\begin{array}{c}-0.73 \\
(-16.62)\end{array}$ & $\begin{array}{c}0.67 \\
(15.27)\end{array}$ \\
\hline \multicolumn{9}{|c|}{ Panel E: West } \\
\hline $60-69$ & $\begin{array}{c}4.40 \\
(100)\end{array}$ & $\begin{array}{c}3.03 \\
(68.97)\end{array}$ & $\begin{array}{c}0.21 \\
(4.91)\end{array}$ & $\begin{array}{c}0.17 \\
(4.01)\end{array}$ & $\begin{array}{c}0.18 \\
(4.10)\end{array}$ & $\begin{array}{c}0.65 \\
(14.82)\end{array}$ & $\begin{array}{c}0.14 \\
(3.18)\end{array}$ & $\begin{array}{c}1.15 \\
(26.11)\end{array}$ \\
\hline $70-79$ & $\begin{array}{c}3.91 \\
(100)\end{array}$ & $\begin{array}{c}2.78 \\
(70.95)\end{array}$ & $\begin{array}{c}0.30 \\
(7.63)\end{array}$ & $\begin{array}{c}-0.11 \\
(-2.78)\end{array}$ & $\begin{array}{c}0.21 \\
(5.33)\end{array}$ & $\begin{array}{c}0.60 \\
(15.27)\end{array}$ & $\begin{array}{c}0.14 \\
(3.57)\end{array}$ & $\begin{array}{c}0.83 \\
(21.41)\end{array}$ \\
\hline $80-89$ & $\begin{array}{c}2.47 \\
(100)\end{array}$ & $\begin{array}{c}1.66 \\
(67.07)\end{array}$ & $\begin{array}{c}0.31 \\
(12.54)\end{array}$ & $\begin{array}{c}-0.31 \\
(-12.73)\end{array}$ & $\begin{array}{c}0.13 \\
(5.26)\end{array}$ & $\begin{array}{c}0.55 \\
(22.19)\end{array}$ & $\begin{array}{c}0.14 \\
(5.66)\end{array}$ & $\begin{array}{c}0.50 \\
(20.39)\end{array}$ \\
\hline 90-99 & $\begin{array}{c}2.85 \\
(100)\end{array}$ & $\begin{array}{c}1.87 \\
(65.42)\end{array}$ & $\begin{array}{c}0.26 \\
(9.05)\end{array}$ & $\begin{array}{c}-0.05 \\
(-1.66)\end{array}$ & $\begin{array}{c}0.13 \\
(4.65)\end{array}$ & $\begin{array}{c}0.50 \\
(17.63)\end{array}$ & $\begin{array}{c}0.14 \\
(4.91)\end{array}$ & $\begin{array}{c}0.73 \\
(25.53)\end{array}$ \\
\hline $00-07$ & $\begin{array}{c}3.37 \\
(100)\end{array}$ & $\begin{array}{c}2.27 \\
(67.42)\end{array}$ & $\begin{array}{c}0.28 \\
(8.25)\end{array}$ & $\begin{array}{c}0.12 \\
(3.60)\end{array}$ & $\begin{array}{c}0.09 \\
(2.73)\end{array}$ & $\begin{array}{c}0.47 \\
(13.85)\end{array}$ & $\begin{array}{c}0.14 \\
(4.15)\end{array}$ & $\begin{array}{c}0.82 \\
(24.33)\end{array}$ \\
\hline $\begin{array}{l}\text { Average } \\
60-07\end{array}$ & $\begin{array}{c}3.40 \\
(100)\end{array}$ & $\begin{array}{c}2.32 \\
(68.25)\end{array}$ & $\begin{array}{c}0.27 \\
(8.00)\end{array}$ & $\begin{array}{c}-0.03 \\
(-1.02)\end{array}$ & $\begin{array}{c}0.15 \\
(4.37)\end{array}$ & $\begin{array}{c}0.55 \\
(16.28)\end{array}$ & $\begin{array}{c}0.14 \\
(4.12)\end{array}$ & $\begin{array}{c}0.81 \\
(23.75)\end{array}$ \\
\hline
\end{tabular}

Note: Results presented throughout this table may not match precisely due to rounding.

\section{ACKNOWLEDGEMENTS}

We thank the anonymous referees for their feedback and the support of Economic Research Southern Africa (ERSA), Cape Town, South Africa.

Address for correspondence: Yasmina Rim Limam, Faculté des Sciences Économiques et de Gestion de Nabeul, Université de Carthage, Tunisia \& IPEG, Johannesburg, South Africa. Tel.: +27.11.717.8128; fax: +27.11.717.8081; e-mail: yrlimam@gmail.com

\section{REFERENCES}

Acemoglu, D., S. Johnson and J. A. Robinson (2005), 'Institutions as a Fundamental Cause of Long-Run Growth', in: P. Aghion and S. N. Durlauf (eds.), Handbook of Economic Growth (Volume 1A, Chapter 6), Elsevier B. V., Amsterdam, pp. 385-472.

Acemoglu, D., P. Aghion and F. Zilibotti (2006), 'Distance to Frontier, Selection, and Economic Growth', Journal of the European Economic Association 4, 37-74.

Aghion, P. and P. Howitt (2007), 'Capital, Innovation, and Growth Accounting', Oxford Review of Economic Policy 23, 79-83. 


\section{Y. R. Limam et al.}

Aigner, D. J., C. A. K. Lovell and P. Schmidt (1977), 'Formulation and Estimation of Stochastic Frontier Production Functions', Journal of Econometrics 6, 21-37.

Baier, S. L., G. P. Dwyer, Jr. and R. Tamura (2006), 'How Important Are Capital and Total Factor Productivity for Economic Growth?', Economic Inquiry 44, 23-49.

Barro, R. and J.-W. Lee (2013), 'A New Data Set of Educational Attainment in the World, 1950-2010', Journal of Development Economics 104, 184-198.

Battese, G. E. and T. J. Coelli (1992), 'Frontier Production Functions, Technical Efficiency, and Panel Data: With Applications to Paddy Farmers in India', Journal of Productivity Analysis 3, 153-169.

Battese, G. E. and G. S. Corra (1977), 'Estimation of a Production Frontier with Application to the Pastoral Zone of Eastern Australia', Journal of Agricultural Economics 21, 169 179.

Benhabib, J. and M. M. Spiegel (1994), 'The Role of Human Capital in Economic Development: Evidence from Aggregate Cross-country Data', Journal of Monetary Economics 34, 143-173.

Berlemann, M. and J.-E. Wesselhöft (2014), 'Estimating Aggregate Capital Stocks Using the Perpetual Inventory Method', Review of Economics/Jahrbuch für Wirtschaftswissenschaften $65,1-34$.

Bosworth, B. P. and S. M. Collins (2003), 'The Empirics of Growth: An Update', Brookings Papers on Economic Activity 34, 113-206.

Caselli, F. (2005), 'Accounting for Cross Country Income Differences', in: P. Aghion and S. Durlauf (eds.), Handbook of Economic Growth (Volume 1A, Chapter 9), Elsevier B. V., Amsterdam, pp. 679-741.

Christopoulos, D. K., G. Siourounis and I. Vlachaki (2015), 'Democratic Reforms, Foreign Aid and Production Inefficiency', Manchester School 84, 363-389.

Easterly, W. and R. Levine (2001), 'It's Not Factor Accumulation: Stylized Facts and Growth Models', World Bank Economic Review 15, 177-219.

Easterly, W., M. Kremer, L. Protchett and L. H. Summers (1993), 'Good Policy or Good Luck? Country Growth Performance and Temporary Shocks', Journal of Monetary Economics 32, 459-483.

Gapinski, J. H. (1999), Economic Growth in the Asia Pacific Region, St. Martin Press, New York, NY.

Gittleman, M., T. ten Raa and E. N. Wolff (2006), 'The Vintage Effect in TFP-Growth: An Analysis of the Age Structure of Capital', Structural Change and Economic Dynamics 17, 306-328.

Guan, Z., S. C. Kumbhakar, R. J. Myers and A. O. Lansink (2009), 'Measuring Excess Capital Capacity in Agricultural Production', American Journal of Agricultural Economics 91, $765-776$.

Harberger, A. C. (1978), 'Perspectives on Capital and Technology in Less Developed Countries', in: M. J. Artis and A. R. Nobay (eds.), Contemporary Economic Analysis, Croom Helm, London, pp. 15-40. (The Frank Paish Lecture presented at the 1977 meetings of the U.K. Association of University Teachers of Economics, Swansea.)

Henderson, D. J. and R. R. Russell (2005), 'Human Capital and Convergence: A Production Frontier Approach', International Economic Review 46, 1167-1205.

Heston, A., R. Summers and B. Aten (2009), 'Penn World Table Version 6.3', Center for International Comparisons of Production, Income and Prices at the University of Pennsylvania.

Hulten, C. R. (1992), 'Growth Accounting When Technical Change is Embodied in Capital', American Economic Review 82, 964-980.

Im, K. S., M. H. Pesaran and Y. Shin (2003), 'Testing for Unit Roots in Heterogeneous Panels', Journal of Econometrics 115, 53-74. 


\section{Output Growth Decomposition with Input Quality Effects}

Islam, N. (1995), 'Growth Empirics: A Panel Data Approach', Quarterly Journal of Economics $110,1127-1170$.

Kamps, C. (2006), 'New Estimates of Government Net Capital Stocks for 22 OECD Countries, 1960-2001', IMF Staff Papers 53, 120-150.

Kerekes, M. (2011), 'Analyzing Patterns of Economic Growth: A Production Frontier Approach', Working Paper, The Free University of Berlin.

King, R. J. and R. Levine (1994), 'Capital Fundamentalism, Economic Development and Economic Growth', Carnegie-Rochester Conference Series on Public Policy 40, 259-292.

Koop, G., J. Osiewalski and M. F. J. Steel (2000), 'Modeling the Sources of Growth in a Panel of Countries', Journal of Business \& Economic Statistics 18, 284-299.

Kumar, S. and R. R. Russell (2002), 'Technological Change, Technological Catch-Up, and Capital Deepening: Relative Contributions to Growth and Convergence', American Economic Review 92, 527-548.

Kumbhakar, S. C. and H.-J. Wang (2005), 'Estimation of Growth Convergence Using a Stochastic Frontier Approach', Economics Letters 88, 300-305.

Lucas, R. E. (1988), 'On the Mechanics of Economic Development', Journal of Monetary Economics 22, 3-42.

Makiela, K. (2009), 'Economic Growth Decomposition. An Empirical Analysis Using Bayesian Frontier Approach', Central European Journal of Economic Modeling and Econometrics $1,333-369$.

Mankiw, G. N., D. Romer and D. N. Weil (1992), 'A Contribution to the Empirics of Economic Growth', Quarterly Journal of Economics 107, 407-437.

Meusen, W. and J. van den Broeck (1977), 'Efficiency Estimation from Cobb-Douglas Production Functions with Composed Error', International Economic Review 18, 435-444.

Miller, S. M. and M. P. Upadhyay (2000), 'The Effects of Openness, Trade Orientation, and Human Capital on Total Factor Productivity', Journal of Development Economics 63, 399-423.

Nissan, E. and F. Niroomand (2006), 'Technological Change and Contribution to Growth and Convergence', Journal of Economic Development 31, 113-133.

Parente, S. L. and E. C. Prescott (2005), 'A Unified Theory of the Evolution of International Income Levels', in: P. Aghion and S. Durlauf (eds.), Handbook of Economic Growth (Volume 1B, Chapter 21), Elsevier B.V, Amsterdam, pp. 1371-1416.

Pires, J. O. and F. Garcia (2012), 'Productivity of Nations: A Stochastic Frontier Approach to TFP Decomposition', Economics Research International 2012, 1-19. https://doi.org/10. $1155 / 2012 / 584869$.

Romer, P. M. (1986), 'Increasing Returns and Long-Run Growth', Journal of Political Economy 94, 1002-1037.

Shinada, N. (2011), 'Quality of Labor, Capital, and Productivity Growth in Japan: Effects of Employee Age, Seniority, and Capital Vintage', Discussion Paper No. 11036, Research Institute of Economy, Trade and Industry (RIETI), Tokyo.

Solow, R. M. (1956), 'A Contribution to the Theory of Economic Growth', Quarterly Journal of Economics 70, 65-94.

Turner, C., R. Tamura and S. Mulholland (2013), 'How Important Are Human Capital, Physical Capital and Total Factor Productivity for Determining State Economic Growth in the United States, 1840-2000?', Journal of Economic Growth 18, 319-371.

Wang, M. and M. C. S. Wong (2012), 'International R\&D Transfer and Technical Efficiency: Evidence from Panel Study Using Stochastic Frontier Analysis', World Development 40, 1982-1998.

Whelan, K. (2007), 'Embodiment, Productivity, and the Age Distribution of Capital', Journal of Macroeconomics 29, 724-740. 